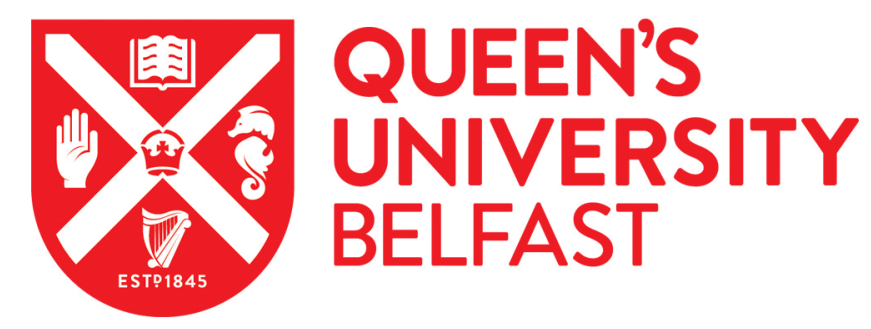

\title{
Effect of grinding on early age performance of high volume fly ash ternary blended pastes with CKD \& OPC
}

Bondar, D., \& Coakley, E. (2017). Effect of grinding on early age performance of high volume fly ash ternary blended pastes with CKD \& OPC. Construction and Building Materials, 136, 153-163.

https://doi.org/10.1016/j.conbuildmat.2017.01.044

\section{Published in:}

Construction and Building Materials

\section{Document Version:}

Peer reviewed version

\section{Queen's University Belfast - Research Portal:}

Link to publication record in Queen's University Belfast Research Portal

\section{Publisher rights}

( 2017 Elsevier Ltd This manuscript version is made available under the CC-BY-NC-ND 4.0 license http://creativecommons.org/licenses/by$\mathrm{nc}-\mathrm{nd} / 4.0 /$ which permits distribution and reproduction for non-commercial purposes, provided the author and source are cited.

\section{General rights}

Copyright for the publications made accessible via the Queen's University Belfast Research Portal is retained by the author(s) and / or other copyright owners and it is a condition of accessing these publications that users recognise and abide by the legal requirements associated with these rights.

Take down policy

The Research Portal is Queen's institutional repository that provides access to Queen's research output. Every effort has been made to ensure that content in the Research Portal does not infringe any person's rights, or applicable UK laws. If you discover content in the Research Portal that you believe breaches copyright or violates any law, please contact openaccess@qub.ac.uk. 
1 Effect of grinding on early age performance of High Volume Fly Ash ternary blended pastes with CKD \& OPC

2 Dali Bondar ${ }^{1}$, Eoin Coakley ${ }^{2}$

$3{ }^{1}$ Research Fellow in School of Natural and Build Environment, Queens University of Belfast, BT9 5AG, UK,

4 Phone: +44 2890974032, E-mail address: D.Bondar@qub.ac.uk

$5{ }^{2}$ Senior Lecturer in School of Energy, Construction and Environment, Coventry University, CV1 5FB, UK

6 Phone: +44 2477658967, E-mail address: eoin.coakley@coventry.ac.uk

\section{Abstract}

9 This study investigated setting times and early age compressive strength of the high volume fly ash (HVFA) blended 10 pastes prepared with ground materials. The pastes consisted of $60 \%$ Fly Ash $+30 \%$ Portland cement (CEM I) $+10 \%$ 11 cement kiln dust (CKD) and tests were carried out for four different fly ashes. In phase 1, all the constituent binder 12 materials (class F-fly ash, CEMI and CKD) were initially mixed in the relevant proportions and were ground for 13 varying time periods (1, 2 and 4 hours). In phase 2, the CEM I and CKD were mixed and ground for different time 14 periods ( 1 and 2 hours) and then added to the unground fly ash. Both wrapped and submerged curing were used 15 for compressive strength test samples. Overall, grinding of constituents appeared to be largely ineffective at 16 increasing 2 day compressive strength although strength enhancements at 28 days were generally observed. Paste 17 samples that were made from interground constituents generally achieved higher 28 day strengths than 18 corresponding pastes where only the activators were ground, although this was not consistent throughout so 19 further investigation is suggested in this area. Submerged curing is generally less effective in increasing compressive 20 strength than wrapped curing as leaching of CKD is suspected to have occurred.

22 Keywords: CKD, intergrinding, separate grinding, particle size distribution (PSD), HVFA ternary pastes

\section{Introduction}

25 Use of high volume fly ash (HVFA) concrete has numerous performance benefits as well as the obvious economic 26 and environmental benefits. Incorporating high volumes of fly ash within a mix improves mix cohesion, reduces 27 heat of hydration, reduces permeability and increases resistance to alkali silica reaction. However, the pozzolanic 28 reaction occurs relatively slowly and therefore increases setting times and reduces the initial rate of strength gain.

29 Increased setting times means that more time has to be allowed before removal of formwork and propping, which 30 would lead to delays and increased formwork costs. The overall aim of this project is to reduce setting times and 31 increase the early age strength of concrete containing high volumes of fly ash. Previous work [1] investigated use 32 of cement kiln dust (CKD) as an activator for fly ash and examined proportioning of binder constituents. The 33 optimum binder proportioning established is investigated within the current study with mechanical grinding of 34 binder constituents to instigate further early age strength enhancements. 


\section{Review of previous work}

\section{Effect of particle size}

40 Erdogdu and Turker [2] tried to interpret the strength of Portland cement - fly ash mortars in terms of the chemical,

41 mineralogical, morphological, and physical properties of different fly ash size fractions. They found that finer

42 fraction groups resulted in higher compressive strength and that using $<45 \mu \mathrm{m}$ ashes gave higher strength than the

43 original ashes containing all size fractions, at all ages tested. For the low lime fly ash tested, the difference in

44 chemical composition between the various size fractions was negligible so the strength enhancement was primarily

45 attributed to particle size (although the same could not be confirmed for the high lime fly ash tested). They

46 calculated equivalent strength from a weighted average (based on the particle size distribution of the original ashes)

47 of the strengths from the various size fractions and found that calculated strengths were lower than measured

48 strengths for both of the original ashes at all ages. This is attributed to the uniform grading distribution in the

49 various size fractions leading to increased porosity in the mortars. The importance of grading of ash particle size

50 for compressive strength gain was highlighted.

51 Chindaprasirt et al [3] investigated fineness of fly ash through sieving and separation using an air classifier. Sieving

52 produced two graded fly ash portions, finer than $75 \mu \mathrm{m}$ and finer than $45 \mu \mathrm{m}$. Separation produced "single size"

53 portions with $65 \%$ of the original ash in the "coarse" portion, the next finest $25 \%$ in the "medium" portion and the

54 finest $10 \%$ in the "fine" portion. Mortars produced with $40 \%$ of fly ash samples generally required less water for a

55 given flow than for an equivalent Portland cement mortar. The water demand of mortar made using $<45 \mu \mathrm{m}$ ash

56 was greater than for $<75 \mu \mathrm{m}$ ash due to the increase in the surface area of the finer particles. 3 day compressive

57 strength of mortars made with $<75 \mu \mathrm{m}$ ash and $<45 \mu \mathrm{m}$ ash increased relative to the original ash by $35 \%$ and $74 \%$

58 respectively. Mortars made with separated ash portions with varied water content based on the consistencies

59 observed 3 day strengths $26 \%$ lower for coarse, $43 \%$ higher for medium and $117 \%$ higher for fine portions relative

60 to the mortar with the original ash. Blaine fineness was measured for all ash portions and the fineness of the graded

$61<45 \mu \mathrm{m}$ ash was similar to the medium separated portion. However, the compressive strength of the graded $<45$

$62 \mu \mathrm{m}$ ash was appreciably higher as it included fine particles (unlike the medium separated portion), which again

63 emphasizes the importance of ash particle size grading.

64 In a separate investigation, Chindaprasirt et al [4] examined compressive strength and pore structure of two Class

$65 \mathrm{~F}$ fly ash portions of median size, $19.1 \mu \mathrm{m}$ and $6.4 \mu \mathrm{m}$. A Mercury intrusion porosimeter was used to measure

66 porosity and average pore diameter within the pastes. The total porosity was consistently lower for the finer ash

67 at all ages and the average pore diameter was smaller as a result of better dispersing and packing of the finer

68 particles. These observations were in agreement with observed higher compressive strengths of the finer ash.

69 Kiattikomol et al [5] investigated the effect of ash fineness through both separation using an air classifier and

70 grinding. They established that there was no significant difference in compressive strength of mortars made with

71 classified or ground fly ashes of similar median particle size. They found that the strength activity index of mortars

72 for a given test age increased with increasing ash fineness. For example, mortars made with ash of median size of

$7330 \mu \mathrm{m}$ achieved an activity index of $80 \%$ after 14 days but mortars from ash with a median size of $15 \mu \mathrm{m}$ achieved

74 the same strength after only 3 days. Between 7 and 14 days, $\approx 3 \%$ increase of strength activity index was observed 
75 when using fly ash with $d_{50}=30 \mu \mathrm{m}$, while $<10 \%$ increase of strength was observed during the same period for an

76 ash of $d_{50}=2 \mu \mathrm{m}$. They also found that when the fineness of each fly ash was increased, mortar setting times

77 reduced.

78 Aydin et al [6] studied strength of mortars with cement replacement levels up to $60 \%$ with unground and ground

79 fly ash. They reported a 3 day strength of $18.1 \mathrm{MPa}$ when the ash was ground to $907 \mathrm{~m}^{2} / \mathrm{kg}$, which was substantially

80 higher than the 6.0 MPa strength recorded for the unground ash $\left(290 \mathrm{~m}^{2} / \mathrm{kg}\right)$. They also examined the effect of

81 various curing regimes and found that higher replacement levels were more sensitive to choice of curing method.

82 Air curing was found to cause a $43 \%$ reduction in 28 day compressive strength (relative to standard water curing)

83 for the mortar including $60 \%$ of the ground ash, which highlights the importance of appropriate curing.

\section{Effect of grinding time}

86 Grinding of cementitious materials is very expensive and energy intensive so investigation of various grinding times

87 is merited with a view to establishing a minimum grinding time beyond which, no significant improvement in paste

88 performance will be observed. Paya et al [7] investigated grinding times for fly ash and reported a $62 \%$ reduction

89 in median diameter after 20 minutes but just a further $15 \%$ reduction up to 60 minutes. They reported that fly ash

90 particles with diameter greater than $30 \mu \mathrm{m}$ were easily crushed using a laboratory mill and the percentage of

91 particles $>30 \mu \mathrm{m}$ after 30 minutes of grinding was negligible. The specific gravity of the ground particles increased,

92 primarily due to the crushing of cenospheres and porous carbon particles. They found that the grinding process

93 caused fly ash particles to become less spherical, thereby lessening their potential for reducing water demand of a

94 concrete mix.

95 Felekoglu et al [8] studied the effect of grinding on strength activity and on water demand of ground high-calcium

96 fly ash. They observed a $6 \%$ reduction in 2 day compressive strength due to grinding for 43 minutes but this was

97 attributed to the $6 \%$ increase in water content to achieve a constant mortar workability. They noted that the change

98 in water demand due to grinding is heavily dependent on initial ash particle shape, surface morphology and

99 porosity. They suggested an optimum fineness of $480 \mathrm{~m}^{2} / \mathrm{kg}$ for the high calcium ash that they tested where the

100 reactivity of the ash was increased but without significantly increasing the specific area and therefore the water 101 demand.

102 Paya et al [9] tested compressive strength of mortars containing $60 \%$ fly ash and $40 \%$ cement within the binder at 103 a curing temperature of $20^{\circ} \mathrm{C}$ for a range of grinding periods for the ash. They found an increase in 3 day 104 compressive strength of $8.8 \%$ for 10 minutes of grinding and $27.5 \%$ for 60 minutes of grinding (relative to the 3 day 105 strength of the mortar containing unground ash). Corresponding strength developments at 28 days were $16.8 \%$ and $10648.1 \%$ for 10 minutes and 60 minutes of grinding respectively.

107 Bouzoubaa et al [10] investigated the effect of grinding fly ashes over a 10 hour period. They observed that the 108 main increase in specific gravity occurred up to two hours due to the crushing of plerospheres and cenospheres. 109 Blaine fineness continually increased over time with the main increase occurring within the first two hours (126\%, $11053 \%$, and $67 \%$ increases in fineness after two hours for the three ashes tested and $272 \%, 146 \%$ and $116 \%$ after ten 111 hours). Water demand initially decreases due to crushing of plerospheres but increases after four hours due to an 
112 increase in irregular shaped particles. Peak strength activity index was recorded after four hours of grinding and

113 this corresponds with the observed trough in water demand.

114 Wang et al [11] investigated various activation methods including intergrinding on blends of $50 \%$ Class $\mathrm{F}$ fly ash and

$11550 \%$ CKD. For the unground blend, $14.9 \%$ was retained on a $45 \mu \mathrm{m}$ sieve but this reduced to $0.11 \%, 0.04 \%$, and $0 \%$

116 after two hours, four hours and six hours of grinding respectively. Although particle size reduction essentially ceased

117 beyond two hours of grinding, further grinding was thought to increase the amorphous phase content of the

118 material. 3 day strength of pastes increased by $28 \%$ and $164 \%$ relative to the unground blend after six hours and

119 twelve hours of grinding respectively. The marked increase in strength up to twelve hours of grinding is largely

120 attributed to mechanochemical activation whereby particle surface modification increases surface free energy,

121 making the particles more reactive.

122 Bouzoubaa et al. [12] carried out an initial series of tests on fly ash - cement binders and used Blaine fineness as a

123 control measure for grinding duration used. However, when comparing the particle size distribution curves of

124 blended cements with laboratory produced Portland cement for a given Blaine fineness, it was found that in the

125 low particle size range $(<5 \mu \mathrm{m})$ the blended cements were coarser, whereas for the high particle size range the

126 reverse is true. They found that although the grinding time for the blended cements to achieve a particular Blaine

127 fineness was shorter, their compressive strength was lower and they attributed this to coarser clinker particles.

128

129 Intergrinding or separate grinding of constituents

130 Bouzoubaa et al [12] carried out a second series of tests on fly ash - cement binders where the effect of both

131 grinding fly ash and cement separately and intergrinding for a period of four hours was investigated. They reported

132 that adding ground fly ash to cement gave consistently higher compressive strengths of mortars than for unground

133 fly ash with 1 day strength increases of $27 \%-46 \%$. Observed increases in Blaine fineness of the ash due to grinding

134 correlated well with observed strength increases with greater strength increases observed for originally coarser

135 ashes. Compressive strength of mortars when fly ash and cement were interground were noticeably higher (than

136 for equivalent mixes where the ash and cement were ground separately) for two of the three ashes tested with

137 minimal change in strength for the third ash. The general increase in strength due to intergrinding is largely

138 attributed to the improved homogeneity of the binder although it is acknowledged that further investigation in this

139 area would be beneficial.

140 Ghiasvand et al [13] suggested that intergrinding binder constituents can influence the relative content of each

141 constituent in different size fractions. For example, a component that is hard to grind becomes concentrated in

142 coarse fractions and vice versa. They investigated inter-grinding and separate grinding on the properties of mortars

143 and concretes made from a Portland cement - Trass blend and observed that intergrinding produced finer particle

144 size distributions in all cases. Cement paste consistency and setting times were found to be unaffected by grinding

145 approach (intergrinding or separate grinding). However, compressive strengths were consistently higher for

146 interground samples (e.g. for 35\% cement replacement, 7 day strengths were $7.5 \%-9.5 \%$ higher for interground

147 constituents). 
148 Erdogdu et al [14] investigated intergrinding and separate grinding of $75 \%$ cement with $25 \%$ natural pozzolan and

149 found that separate grinding consistently produced an equal or larger amount of material above a given sieve size.

150 This effect was more pronounced for greater mill energy consumption (i.e. longer grinding periods). 2 day strengths

151 of separately ground pastes were $94 \%$ of interground pastes of equivalent Blaine fineness but the difference in

152 strength decreases with age. This was attributed to the overall coarser particle size distribution and lower

153 homogeneity of the separately ground blend.

154 Ryou [15] blended 65\% cement kiln dust (CKD) with 35\% fly ash and examined the effect of grinding separately or 155 intergrinding over various periods of time. When comparing blends ground separately or together for the same 156 time period (of 4 hours), he observed that the mean particle size was smaller and a greater proportion was passing 157 a $0.45 \mu \mathrm{m}$ sieve when the constituents were ground separately. Initial paste setting times were also $27 \%$ shorter 158 for the ground separately blend.

159 Bentz et al [16] suggested that one limitation of the cement manufacture industry is that Portland cement is 160 optimized for use as a pure cement as opposed to within a blended cement. Their approach was to optimize the 161 particle sizes of cement and fly ash to maximize strength of the blended product and found that using a finer cement 162 (with a similar ash size) generally gave a higher early age strength but the magnitude of the increase reduced as the 163 replacement level increased. They found that blending a finer cement with a relatively course ash boosted early 164 ash strength without significantly affecting the overall particle size distribution and therefore water demand for a 165 particular workability. Therefore, although the majority of literature available suggests that intergrinding the 166 constituent materials enhances early age strength, Bentz's study highlights the beneficial effects of grinding the 167 cement only.

\section{Significance of the current study}

170 From the review of previous work in this area, most studies of cement and fly ash binders focus on fly ash levels 171 only up to $50 \%$. Only one study, Wang et al. 2007, has investigated intergrinding of CKD and fly ash (without cement 172 clinker). In this study, no setting time measurements were recorded so any effect that grinding has on setting time 173 cannot be evaluated. They also did not examine the effect of separate grinding of the activator on compressive 174 strength or grinding efficiency in relation to median particle size or compressive strength. The significance of this 175 work is to study if grinding can be effective in reducing setting times and increasing early age strength of pastes 176 containing high volumes of fly ash with CEM I and CKD and to evaluate parameters such as intergrinding vs. activator 177 only grinding, grinding duration and curing condition.

\section{Experimental work}

180 In this study, four different class F fly ash samples, Portland cement (CEM I) and cement kiln dust (CKD) were ground 181 for varying time periods. The powder proportions were taken from the optimum proportions (60\% fly ash, $30 \%$ CEM 182 I and 10\% CKD) established in previous work [1]. The chemical composition of the raw materials was determined 183 using X-ray fluorescence (XRF) carried out using a PAN analytical Axios Advanced XRF spectrometer and the resulting 184 oxide proportions are given in Table 1. The density, Blaine fineness and percentage retained on a $45 \mu \mathrm{m}$ sieve for 
185 the raw materials were determined in accordance with BS EN 196-6 and these physical properties are presented in

186 Table 2. Particle size distribution of the raw materials (Figure 1) was carried out using a Malvern Mastersizer 2000

187 with a Hydro MU sampler and the median particle size established is also included in Table 2.

188 In phase 1 of the experimental work, all the constituent binder materials (class F-fly ash, CEMI and CKD) were 189 initially mixed in the relevant proportions and were ground for varying time periods (1, 2 and 4 hours), based on 190 the observations from references [12 - 14]. In phase 2, the CEM I and CKD were mixed and ground for varying time 191 periods ( 1 and 2 hours) and then added to the unground fly ash, in line with observations from Bentz [16] where 192 only the activator material was ground. Grinding took place in a laboratory scale ball mill and $3 \mathrm{~kg}$ of each of 12 $193 \mathrm{~mm}, 18 \mathrm{~mm}$ and $24 \mathrm{~mm}$ diameter grinding media was used to grind $3 \mathrm{~kg}$ of powder. Where intergrinding of all 194 constituents took place, grinding continued for one hour, two hour and four hour durations and where only the 195 activators (CEM I and CKD) were ground, grinding durations of one hour and two hours were used. Measurement 196 of particle size distribution of the blends was also carried out once grinding was complete. Also, the morphology of 197 the ground powders was assessed from scanning electron microscopy (SEM) images taken by a JOEL 6060LV 198 Scanning Electron Microscope.

199 Paste mixes were prepared for blends of both the unground and ground constituents using a Hobart style mixer.

200 All powder materials were initially dry mixed to ensure homogeneity (if not already premixed through the grinding 201 process). Water was subsequently added with a water to binder ratio of 0.3 used throughout the experimental 202 programme. A portion of the paste mixture was used to measure initial and final setting time in accordance with 203 BS EN 196-3. From each paste mix, eighteen $50 \mathrm{~mm}$ cubes were cast to measure compressive strength. The 204 specimens were compacted in three layers using a vibrating table, covered in plastic sheeting and left to set for 24 205 hours. Samples were then demoulded and nine of the samples were submerged under water maintained at $20^{\circ} \mathrm{C}$. 206 The remaining nine samples were shrink-wrapped with plastic sheeting and kept in a moist curing container with 207 water beneath the mesh that the samples were placed on. These samples were kept at approximately $20^{\circ} \mathrm{C}$ and $20890 \%$ relative humidity until required for testing. This curing regime was selected to ensure that no leaching occurred 209 due to the presence of CKD as an activator, which may be the case for submerged curing. 2 day, 7 day and 28 day 210 compressive strength was determined, taken as the average of three samples for each test age and curing regime. 211 Note that strengths for the pastes with unground particles were measured for wrapped curing only and these 212 results are shown in the relevant graphs to provide a frame of reference. Subsequent to compressive strength 213 testing, pieces of the crushed samples from selected mixes were retained for assessment of paste chemical 214 composition by XRF analysis.

\section{Results and discussion}

217 When presenting and discussing results, the following coding system is used:

218 UG = unground (i.e. original raw materials)

219 IG = interground (i.e. blending fly ash, cement and CKD in the relevant proportions and then grinding)

220 AG = activator grinding (i.e. blending cement and CKD in the relevant proportions, grinding and then mixing with 221 the unground fly ash) 
$2220 / 1 / 2 / 4=$ time of grinding in hours

223 FA1 / FA2 / FA3 / FA4 = fly ash sample based on information given in tables 1 and 2

$224 \mathrm{~W} / \mathrm{S}=$ wrapped $/$ submerged curing regime

225 For example, IG-1-FA2 is referring to the powder blend or resulting paste mix where fly ash 2 was interground with

226 cement and CKD in the relevant proportions for 1 hour.

227 Fineness and particle shape

228 Table 3 shows the specific gravity and median particle size for all interground samples of fly ash, cement and CKD

229 and also for samples of cement and CKD that were ground in the relevant proportions before being blended with

230 the unground fly ash. The variation in specific gravity between interground samples containing different fly ashes

231 generally correlated with the specific gravity of the raw materials as expected (e.g. ash 2 had a significantly higher

232 specific gravity than the other ashes and interground samples containing this ash had higher specific gravity values).

233 For fly ash 1, 3 and 4, the specific gravity of interground blends tended to increase with prolonged grinding. This

234 can be attributed to crushing of low-density cenospheres exposing higher density wall material and plerospheres

235 liberating small dense particles. However, for fly ash 2, a slight reduction in the interground blend specific gravity

236 was observed for increasing grinding time, which suggests fly ash 2 contains denser, solid particles that are resistant

237 to fragmentation and contains few cenospheres and plerospheres.

238 When evaluating the effect of grinding duration on median particle size values from Table 3, particle size generally

239 appeared to decrease after one hour of grinding. From the grinding efficiency diagrams (Figure 2), the minimum

240 particle size was achieved after one hour for ash 1, 3 and 4 and after two hours for ash 2. Further grinding was not

241 effective due to agglomeration of the particles or overgrinding of the softer material with the harder material.

242 These two effects meant that particle size did not reduce further with increased grinding time. To investigate this

243 further, sample particle size distribution plots for interground blends made with ash 1 and ash 2 were produced

244 and plots for the corresponding unground blends were included (Figure 3). The unground blend was coarsest

245 throughout the range and the largest reduction in particle size occurs near the coarse end of the range in both

246 cases. As can be seen for interground blends made with ash 1 and ash 2, D90 changed from $62.5 \mu \mathrm{m}$ to $45.5 \mu \mathrm{m}$

247 and $37.7 \mu \mathrm{m}$ respectively while D10 did not change significantly. This is largely attributed to crushing of hollow

248 cenospheres within the fly ash. Felekoglu et al [8] emphasize that small particles within raw fly ash are naturally

249 more reactive due to their rapid rate of cooling during processing and that reduction in coarse particle size should

250 be prioritized. Looking specifically at the coarser end of the range, the fineness of the ground blend achieved was

251 virtually identical for all three grinding durations, which suggests that grinding beyond one hour is largely

252 ineffective.

253 Figure 4 shows particle size distribution plots when grinding the activators only (i.e. $75 \%$ CEM I + 25\% CKD) and 254 again includes the corresponding unground blend. Grinding caused a reduction in particle size throughout the 255 range. D90 reduced from $48.9 \mu \mathrm{m}$ to $41.7 \mu \mathrm{m}$ and median particle size changed from $20.5 \mu \mathrm{m}$ to $13.0 \mu \mathrm{m}$ while D10 $256 \mathrm{had}$ a reduction from $4.7 \mu \mathrm{m}$ to $2.0 \mu \mathrm{m}$. These are all large reductions considering the percentage size reductions. 257 Therefore, reduction in activator particle size has contributed to the observed reduction in the interground blends. 258 Again, there appeared to be little benefit to grinding beyond one hour for activator only grinding. 
259 Figure 5 compares particle size distribution plots for unground blends with one hour interground blends and one 260 hour activator ground blends (after being blended with unground fly ash). For both ash 1 and ash 2, only a slight 261 reduction in particle size was observed for activator only grinding at the coarse end of the particle size range caused 262 by a reduction in particle size for CEM I and more particularly, the coarse CKD particles. As expected, intergrinding 263 caused a more significant reduction in particle size at the coarse end of the range as the fly ash (which constitutes $26460 \%$ of the material by mass) was included in the grinding process. However, when considering the finer end of the 265 particle range for blends with both ashes presented, grinding the activator only produced a slightly finer overall 266 blend. This is largely attributed to grinding of CKD particles, which was more effective when the CKD constitutes $26725 \%$ of the material being ground when only the activators were ground.

268 Figure 6 shows SEM images of the individual raw materials. Visual comparison of the different types of fly ash shows 269 that ash 1 and ash 3 are more porous with more coarse particles than ash 2 and ash 4 (which correlates with 270 observations from PSD curves). It is apparent that all fly ash samples contain spherical particles whereas CEM I has 271 irregular shaped particles and CKD particles have a spongy appearance. Figure 7 shows SEM images for interground 272 blends made with ash 1 and ash 2 for varying time periods. For both ashes shown, the porosity of the blend after 273 two hours and four hours of grinding appears to be lower than for one hour of grinding. However, the most uniform 274 and dense blend seems to result after two hours of grinding. Having said that, some relatively large spherical fly ash 275 particles are still apparent from the images, even after four hours of grinding. Figure 8 shows activator only ground 276 powders prior to addition of the unground fly ash. By comparing these images to those for the raw CEM I and CKD, 277 it is apparent that the porosity of the activator reduces with increased grinding time. This generally correlates with 278 observations from the relevant PSD curve, Figure 4.

\section{Setting times}

281 Figure 9a shows initial and final setting times for the pastes with unground constituents and corresponding pastes 282 with interground constituents. For all four fly ashes, initial and final setting times were consistently longer for 283 increasing grinding times. Similar trends were observed for pastes with ground activators and unground fly ash 284 (Figure 9b) although shorter setting times than for equivalent interground pastes were generally observed. The 285 shortest setting times were generally recorded for pastes with the finest particles after one hour of intergrinding 286 or activator only grinding. These observations agree with the findings from Kiattikomol et al [5] and Ryou [15] where 287 setting times reduced with increasing particle fineness. The current investigation used a water to binder ratio of 0.3 288 based on consistence of pastes with unground constituents from previous work [1]. However, Kiattikomol et al [5] 289 used water binder ratios of $0.67-0.73$ and Ryou [15] used a water binder ratio of 0.5. Felekoglu et al [8] found that 290 increasing fineness of fly ash increases water demand caused by the increase in specific surface of ash particles. It 291 is acknowledged that the shape of the particles also affects the water demand. Grinding produces fine angular and 292 fragmented particles which tends to increase water demand but Chindaprasirt et al. [3] found that the use of fine 293 fly ash reduces the water requirement of the mortar mix if the fine fly ash surface is smooth. In this study the water 294 to binder ratio of 0.3 showed enough water for having a fluid mix based on the observation. However, where 
295 grinding is being used to increase reactivity of binder constituents, the increased fineness of the constituent

296 particles should be taken into account when selecting an appropriate water to binder ratio.

297

298 Compressive strength of pastes

299 Figure 10 compares 2 day, 7 day and 28 day compressive strengths of the pastes with unground constituents to the 300 corresponding strengths for interground blends ground for varying time periods. Figure 10a shows results for 301 wrapped cured interground pastes and Figure 10b show results for submerged cured pastes. The submerged cured 302 samples were taken out of the curing tank 24 hours before crushing so that the specimen condition was similar to 303 the wrapped cured samples for strength measurement. The strengths for unground pastes were measured for 304 wrapped curing as a frame of reference and the highest strength for the unground pastes at different ages was for 305 ash 2, which was the ash with the smallest median particle size and highest density. When examining wrapped 306 curing results, grinding appeared to have a negligible or a negative effect on 2 day strengths. Apart from ash 2 , 307 samples after one hour and two hours of intergrinding achieved similar strengths to the unground sample. Over 308 time, the main increases in strength were typically observed between 7 and 28 days. Longer term strengths 309 generally appear to increase up to two hours of intergrinding but a decrease in strength is observed for continued 310 grinding up to four hours. This agrees with grinding efficiency diagrams (Figure 2) which show the minimum median 311 particle size resulted for around two hours of grinding. Observed strengths generally correlated well with the 312 fineness of interground blends. For submerged curing, increasing grinding time generally appeared to increase 2 313 day strength. However, as with wrapped cured samples, two hours of intergrinding appeared to be the optimum 314 duration to maximize 7 day and 28 day strength.

315 Figure 11 compares 2 day, 7 day and 28 day compressive strengths of the pastes with unground constituents to the 316 corresponding strengths of pastes with ground activators and unground fly ash. When examining 2 day strength 317 results for wrapped cured pastes (Figure 11a), grinding of the activators appeared to have mixed effects. For two 318 hours of activator grinding, increases in 2 day strength (relative to the corresponding control paste) were observed 319 for ash 1, ash 3 and ash 4. The median size of the ground activators was lower than these ashes (Tables 2 and 3), 320 which makes the activators more reactive to increases the rate of dissolution of fly ash at early age. However, as 321 with the corresponding interground samples, a reduction in 2 day strength relative to the control was observed for 322 the ash 2 paste due to grinding of constituents as the median size for ash 2 was lower than the ground activators.

323 The effect of activator grinding on 7 day strengths was relatively low but increased activator grinding time generally 324 tended to increase 28 day strengths. However, for a given grinding duration, interground samples (that were 325 wrapped cured) generally achieved higher 28 day strengths than activator only ground samples. This is in line with 326 observations from Bouzoubaa et al [12] and Ghiasvand et al [13]. For the corresponding submerged cured samples 327 (Figure 11b), observations in relation to 2 day strengths were similar to those for the wrapped cured samples. 328 However, longer term strengths are more sporadic and no clear trend is evident. For submerged curing, the 329 beneficial effect of intergrinding (as opposed to activator only grinding) on 28 day strength was not as evident as it 330 was for wrapped curing. 
331 When comparing strength results from the different ash sources, the 2 day strength of the control paste made with 332 ash 2 is appreciably higher than for the remaining ashes $\left(16.36 \mathrm{~N} / \mathrm{mm}^{2}\right.$ compare to others which were 9.57 to $33311.11 \mathrm{~N} / \mathrm{mm}^{2}$ ) (Figure 10). This links to the observations made above that grinding of constituent materials appears 334 to reduce the 2 day strength of samples made with ash 2. With the exception of the coarse end of the range for ash 3354 , ash 2 is notably finer than the other ashes throughout the particle range, Figure 1, which goes some way towards 336 explaining those observations. As can be seen in Figure 12, there is little variation in 7 day strengths for the control 337 pastes but the 28 day strength of the paste made with ash 4 is notably lower than for the other ashes.

338 As stated above, submerged curing led to higher 2 day strengths for interground samples but the curing regime had 339 minimal effect on 2 day strengths for activator only ground samples. However, wrapped curing generally appeared 340 to be more effective than submerged curing at increasing 28 day compressive strength for all pastes. This is 341 apparent from Figure 13 which shows correlations between compressive strength and median particle size for 342 wrapped cured and submerged cured samples. Compressive strength tended to decrease at all ages with increasing 343 median particle size as would be expected. However, 28 day strengths of submerged cured samples did not follow 344 this trend. Kunal et al [17] emphasise that many phases in CKD are unstable or highly soluble and may dissolve 345 completely upon contact with water. Therefore, leaching of CKD may have occurred for submerged cured samples 346 over the 28 day curing period and hindered compressive strength gain.

348 Chemical analysis of cementitious products

349 XRF analysis was carried out on crushed paste samples from 28 day testing for selected mixes and results are shown 350 in Table 4. In this investigation, CKD was used as an activator and the water-soluble alkalis $\left(\mathrm{Na}_{2} \mathrm{O}+\mathrm{K}_{2} \mathrm{O}\right)$ that are 351 responsible for the activation of fly ash are shown in Table 4. Comparing this information with the initial proportion 352 of alkalis content in the mixes (can be calculated by multiplying the oxide content of individual raw materials (Table 353 1) by the proportion of the raw materials in a given mix (i.e. 60\% fly ash, 30\% CEM I and 10\% CKD) and then 354 calculating the total. The result shows that $70 \%$ to $86 \%$ of alkalis in CKD contributed to the activation of fly ash. 355 Overall, the variation in oxide composition between control pastes and the corresponding pastes that include 356 ground constituents is relatively low. Therefore, any observed changes in paste behaviour due to grinding are 357 primarily attributable to physical changes in particle size and shape. An indication of the level of reactivity can be 358 established by comparing the proportion of calcium content observed in the paste samples (Table 4) to the total 359 proportion of calcium content in the original mixes. The initial proportion of calcium content in the mixes can be 360 calculated using the same process as for the alkalis content. The percentage of reacted calcium content was 361 calculated for selected mixes and is presented at the bottom of Table 4 . When comparing interground with activator 362 only ground pastes for ash 1 and ash 2, activator only ground pastes showed higher proportions of reacted calcium 363 content. It should be mentioned that the reacted fly ash in different formulation gives rise to the calcium silicate 364 hydrate and alkali calcium silicate hydrate gels in different cases.

367 Within the current investigation, the following conclusions can be reached: 
1. When examining PSD curves of ground constituents, grinding beyond one hour is not effective at reducing particle size.

2. The shortest setting time for interground blends pastes seems to occur for the finest blend but the setting time for equivalent activator only ground pastes are generally shorter.

3. When examining compressive strength values, two hours of grinding appears to be the optimum grinding duration which suggests that mechanical activation induces further strength enhancements beyond one hour of grinding.

4. Grinding of constituents appeared to be largely ineffective at increasing 2 day compressive strength but generally enhanced 28 day compressive strength.

5. 2 day strengths of activator only ground pastes were slightly better than for equivalent interground pastes, particularly when the median particle size of the ground activators was less than that for the unground fly ash.

6. Paste samples that were made from interground constituents generally achieved $18 \%$ to $40 \%$ higher 28 day strengths than corresponding pastes where only the activators were ground, and this trend was more apparent for the wrapped curing regime.

7. Submerged curing is generally less effective in increasing compressive strength than wrapped curing as leaching of CKD is suspected to have occurred. 
Table 1: Relative oxide contents and loss on ignition (LOI) of raw materials

\begin{tabular}{|c|c|c|c|c|c|c|}
\hline Oxides & Fly ash 1 & Fly ash 2 & Fly ash 3 & Fly ash 4 & CEM I & CKD \\
\hline $\mathrm{SiO}_{2}$ & 52.15 & 51.16 & 56.62 & 58.70 & 19.63 & 15.46 \\
\hline $\mathrm{TiO}_{2}$ & 0.87 & 1.01 & 0.93 & 1.030 & 0.26 & 0.23 \\
\hline $\mathrm{Al}_{2} \mathrm{O}_{3}$ & 19.61 & 24.34 & 22.21 & 27.96 & 4.71 & 3.80 \\
\hline $\mathrm{Fe}_{2} \mathrm{O}_{3}$ & 7.10 & 10.17 & 5.96 & 4.28 & 3.25 & 2.55 \\
\hline $\mathrm{MnO}$ & 0.07 & 0.05 & 0.05 & 0.04 & 0.09 & 0.08 \\
\hline MgO & 2.00 & 1.46 & 1.79 & 1.23 & 1.17 & 0.97 \\
\hline $\mathrm{CaO}$ & 4.40 & 2.79 & 5.69 & 2.24 & 64.09 & 54.18 \\
\hline $\mathrm{Na}_{2} \mathrm{O}$ & 1.06 & 1.28 & 0.83 & 0.71 & 0.27 & 0.56 \\
\hline $\mathrm{K}_{2} \mathrm{O}$ & 1.93 & 2.57 & 1.95 & 2.13 & 0.73 & 4.90 \\
\hline $\mathrm{P}_{2} \mathrm{O}_{5}$ & 0.45 & 0.35 & 0.38 & 0.33 & 0.20 & 0.15 \\
\hline $\mathrm{SO}_{3}$ & 0.54 & 0.26 & 0.61 & 0.29 & 2.94 & 3.84 \\
\hline LOI & 9.48 & 4.35 & 2.98 & 1.00 & 3.22 & 13.25 \\
\hline Total & 99.66 & 99.79 & 100.00 & 99.94 & 100.56 & 99.97 \\
\hline
\end{tabular}

Table 2: Physical properties of raw materials

\begin{tabular}{|c|c|c|c|c|}
\hline Material & $\begin{array}{c}\text { Density } \\
\left(\mathbf{g} / \mathbf{c m}^{\mathbf{3}}\right)\end{array}$ & $\begin{array}{c}\text { Fineness } \\
\left(\mathbf{c m}^{\mathbf{2}} \mathbf{/ g}\right)\end{array}$ & $\begin{array}{c}\text { Retained on } \mathbf{4 5} \boldsymbol{\mu m} \\
\text { sieve } \mathbf{( \% )}\end{array}$ & $\begin{array}{c}\text { Median particle } \\
\text { size }(\boldsymbol{\mu m})\end{array}$ \\
\hline Fly ash 1 & 2.37 & 3987 & 15.6 & 20.1 \\
\hline Fly ash 2 & 2.72 & 3657 & 12.6 & 12.5 \\
\hline Fly ash 3 & 2.37 & 4110 & 15.3 & 19.4 \\
\hline Fly ash 4 & 2.33 & 3741 & 2.8 & 15.9 \\
\hline CEM I & 3.21 & 3495 & 4.8 & 19.3 \\
\hline CKD & 2.77 & 2454 & 20.5 & 26.7 \\
\hline
\end{tabular}


Table 3: Specific gravity and median particle size of unground and ground blends

\begin{tabular}{|l|c|c|}
\hline \multicolumn{1}{|c|}{ Sample type } & Specific gravity & $\begin{array}{c}\text { Median particle } \\
\text { size }(\boldsymbol{\mu m})\end{array}$ \\
\hline IG-0-FA1 & 2.66 & 20.5 \\
\hline IG-1-FA1 & 2.66 & 15.7 \\
\hline IG-2-FA1 & 2.63 & 17.7 \\
\hline IG-4-FA1 & 2.70 & 18.9 \\
\hline IG-0-FA2 & 2.88 & 15.9 \\
\hline IG-1-FA2 & 2.74 & 12.8 \\
\hline IG-2-FA2 & 2.73 & 12.3 \\
\hline IG-4-FA2 & 2.71 & 14.1 \\
\hline IG-0-FA3 & 2.67 & 20.1 \\
\hline IG-1-FA3 & 2.66 & 15.1 \\
\hline IG-2-FA3 & 2.63 & 17.0 \\
\hline IG-4-FA3 & 2.71 & 18.2 \\
\hline IG-0-FA4 & 2.64 & 18.0 \\
\hline IG-1-FA4 & 2.62 & 13.9 \\
\hline IG-2-FA4 & 2.60 & 14.7 \\
\hline IG-4-FA4 & 2.67 & 16.1 \\
\hline AG-1 $*$ & 3.06 & 13.7 \\
\hline AG-2* & & \\
\hline
\end{tabular}


444 Table 4: Relative oxide content, loss on ignition (LOI) and percentage of reacted fly ash in cementitious products

\begin{tabular}{|c|c|c|c|c|c|c|c|c|c|c|}
\hline Oxides & $\begin{array}{l}\text { UG-0- } \\
\text { FA1 }\end{array}$ & $\begin{array}{l}\text { IG-2- } \\
\text { FA1 }\end{array}$ & $\begin{array}{c}\text { AG-2- } \\
\text { FA1 }\end{array}$ & $\begin{array}{l}\text { UG-0- } \\
\text { FA2 }\end{array}$ & $\begin{array}{l}\text { IG-2- } \\
\text { FA2 }\end{array}$ & $\begin{array}{c}\text { AG-2- } \\
\text { FA2 }\end{array}$ & $\begin{array}{l}\text { UG-0- } \\
\text { FA3 }\end{array}$ & $\begin{array}{c}\text { AG-2- } \\
\text { FA3 }\end{array}$ & $\begin{array}{l}\text { UG-0- } \\
\text { FA4 }\end{array}$ & $\begin{array}{r}\text { AG-2- } \\
\text { FA4 }\end{array}$ \\
\hline $\mathrm{SiO}_{2}$ & 35.34 & 40.91 & 36.43 & 34.30 & 35.51 & 35.41 & 38.59 & 38.67 & 39.30 & 39.31 \\
\hline $\mathrm{TiO}_{2}$ & 0.59 & 0.56 & 0.59 & 0.65 & 0.67 & 0.68 & 0.66 & 0.65 & 0.70 & 0.71 \\
\hline $\mathrm{Al}_{2} \mathrm{O}_{3}$ & 12.22 & 11.73 & 12.47 & 14.43 & 15.02 & 15.19 & 14.09 & 14.04 & 17.06 & 17.06 \\
\hline $\mathrm{Fe}_{2} \mathrm{O}_{3}$ & 4.62 & 4.41 & 4.61 & 6.09 & 6.62 & 6.31 & 4.29 & 4.30 & 3.33 & 3.32 \\
\hline MnO & 0.04 & 0.04 & 0.04 & 0.04 & 0.06 & 0.04 & 0.04 & 0.04 & 0.03 & 0.03 \\
\hline MgO & 1.49 & 1.39 & 1.46 & 1.19 & 1.24 & 1.19 & 1.40 & 1.39 & 1.09 & 1.07 \\
\hline $\mathrm{CaO}$ & 26.36 & 22.55 & 24.48 & 26.55 & 23.97 & 24.56 & 25.37 & 25.46 & 24.18 & 23.84 \\
\hline $\mathrm{Na}_{2} \mathrm{O}$ & 0.61 & 0.63 & 0.61 & 0.74 & 0.75 & 0.78 & 0.56 & 0.54 & 0.48 & 0.47 \\
\hline $\mathrm{K}_{2} \mathrm{O}$ & 1.28 & 1.56 & 1.24 & 1.78 & 1.80 & 1.88 & 1.61 & 1.63 & 1.74 & 1.71 \\
\hline $\mathrm{P}_{2} \mathrm{O}_{5}$ & 0.28 & 0.27 & 0.28 & 0.22 & 0.25 & 0.23 & 0.25 & 0.25 & 0.22 & 0.22 \\
\hline $\mathrm{SO}_{3}$ & 2.17 & 1.98 & 1.68 & 2.64 & 1.81 & 2.07 & 1.71 & 1.94 & 1.68 & 1.66 \\
\hline LOI & 14.61 & 14.02 & 16.16 & 11.36 & 12.40 & 11.84 & 11.31 & 11.08 & 10.08 & 10.46 \\
\hline Total & 99.61 & 100.05 & 100.05 & 99.99 & 100.10 & 100.18 & 99.88 & 99.99 & 99.89 & 99.86 \\
\hline Reacted & 96.60 & 82.63 & 89.70 & 100.87 & 91.07 & 93.31 & 90.41 & 90.73 & 93.04 & 91.73 \\
\hline
\end{tabular}



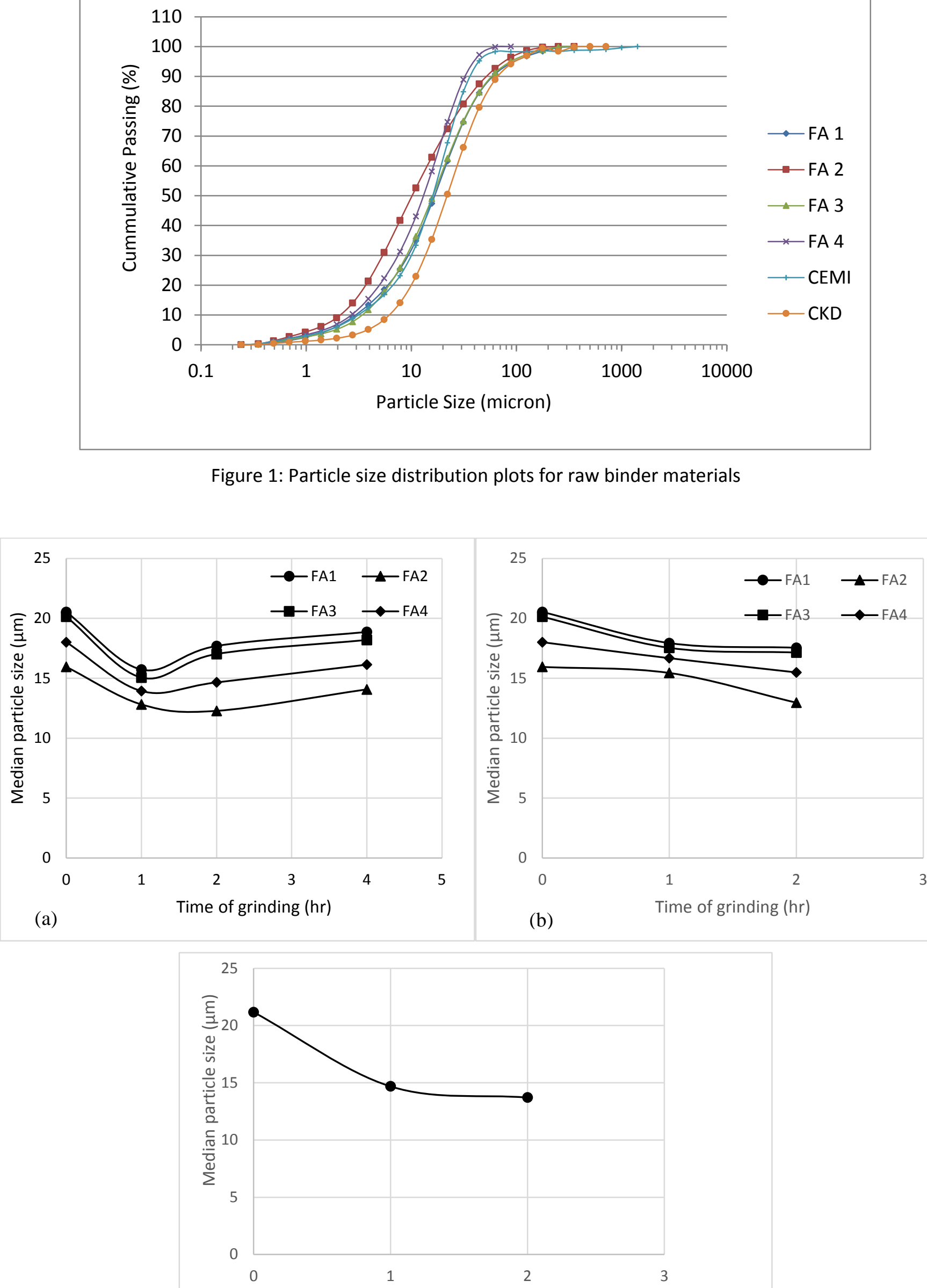


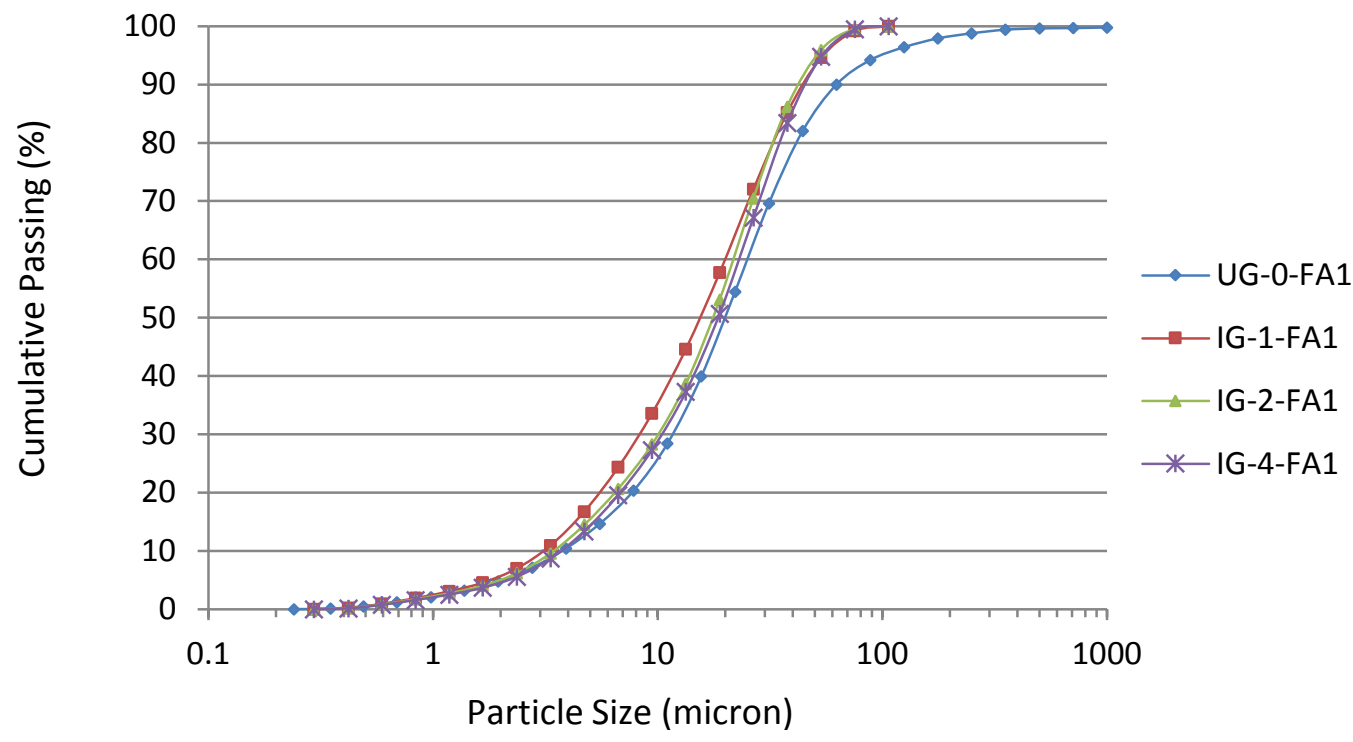

465

(a)

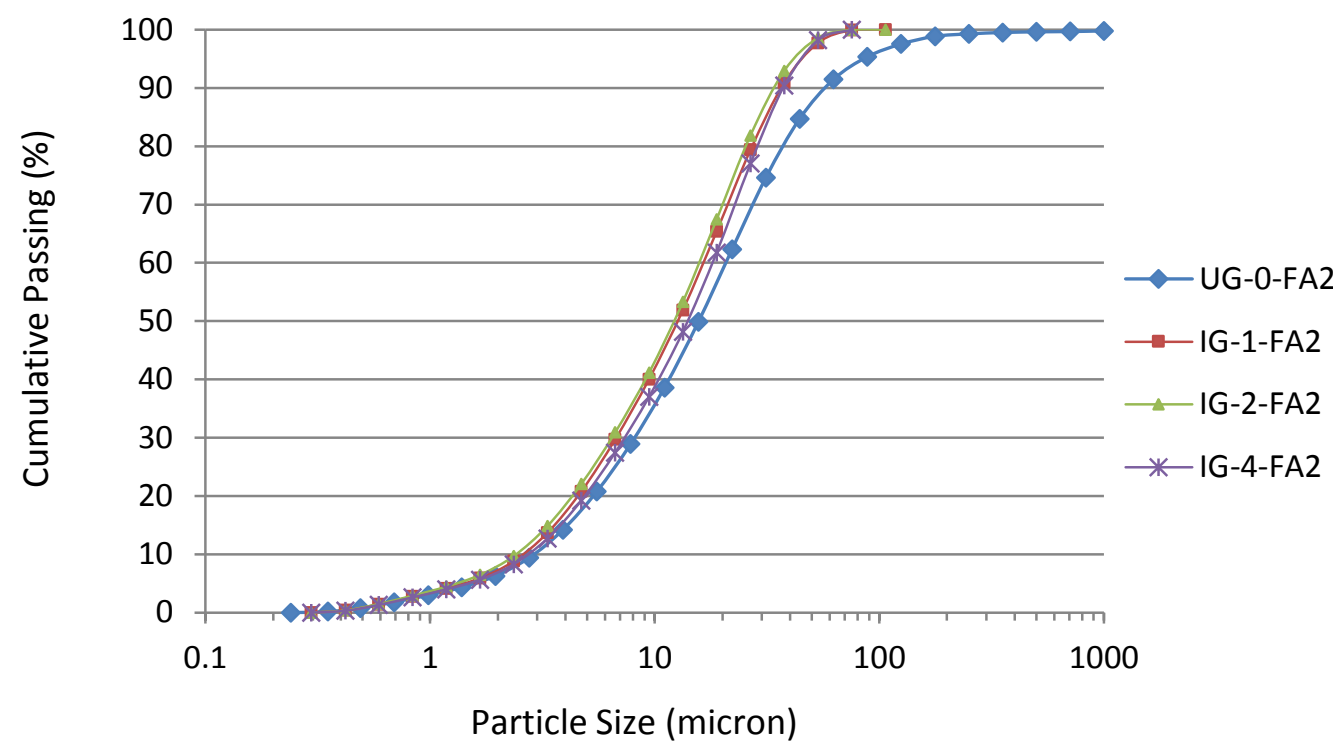

(b)

468 Figure 3: Particle size distribution plots for interground blends made with (a) fly ash 1 and (b) fly ash 2 ground for 469 varying time periods

470 


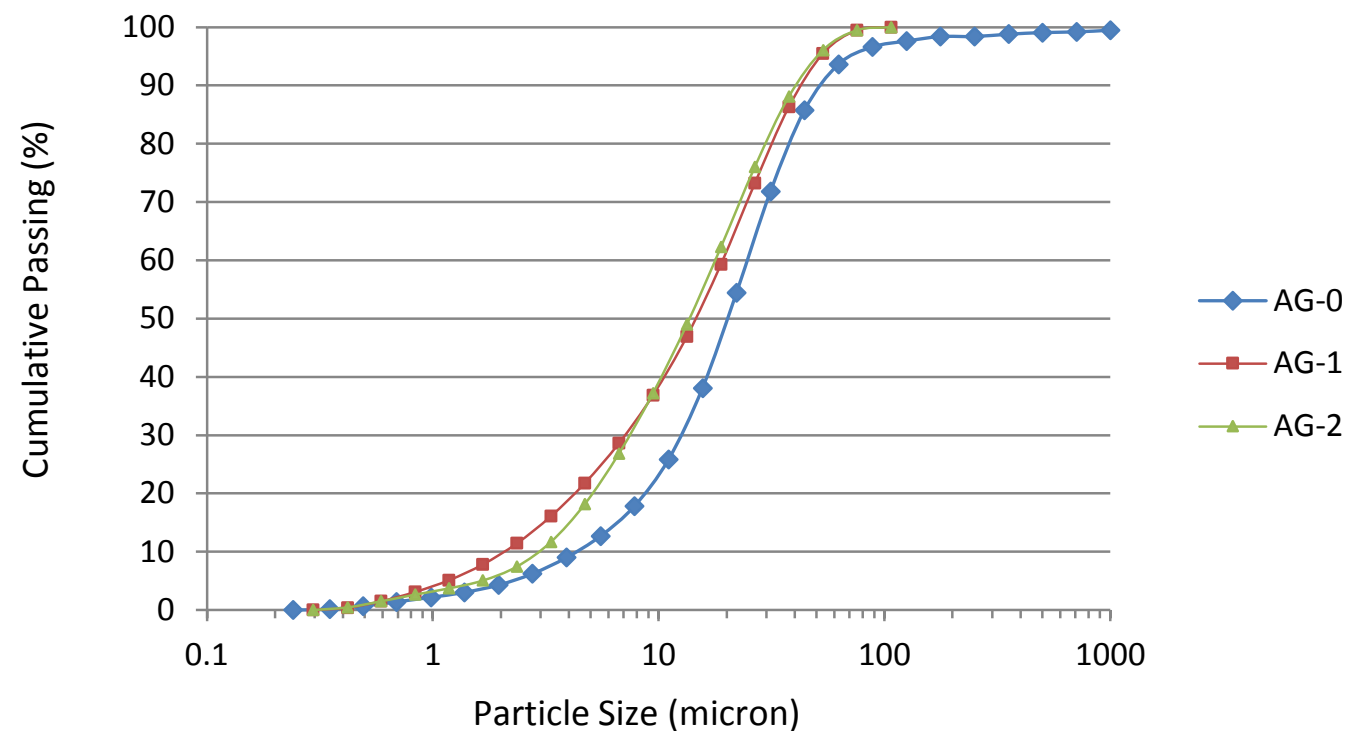
periods 


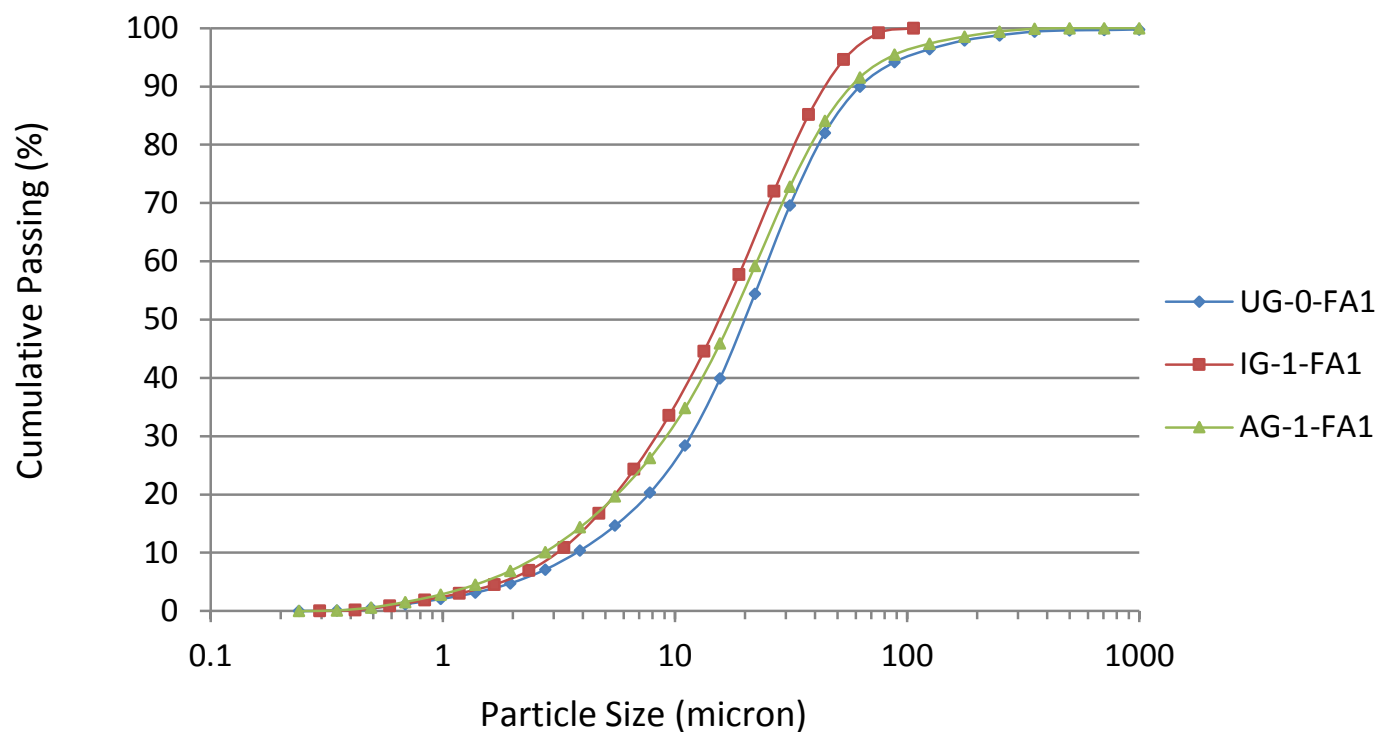

(a)

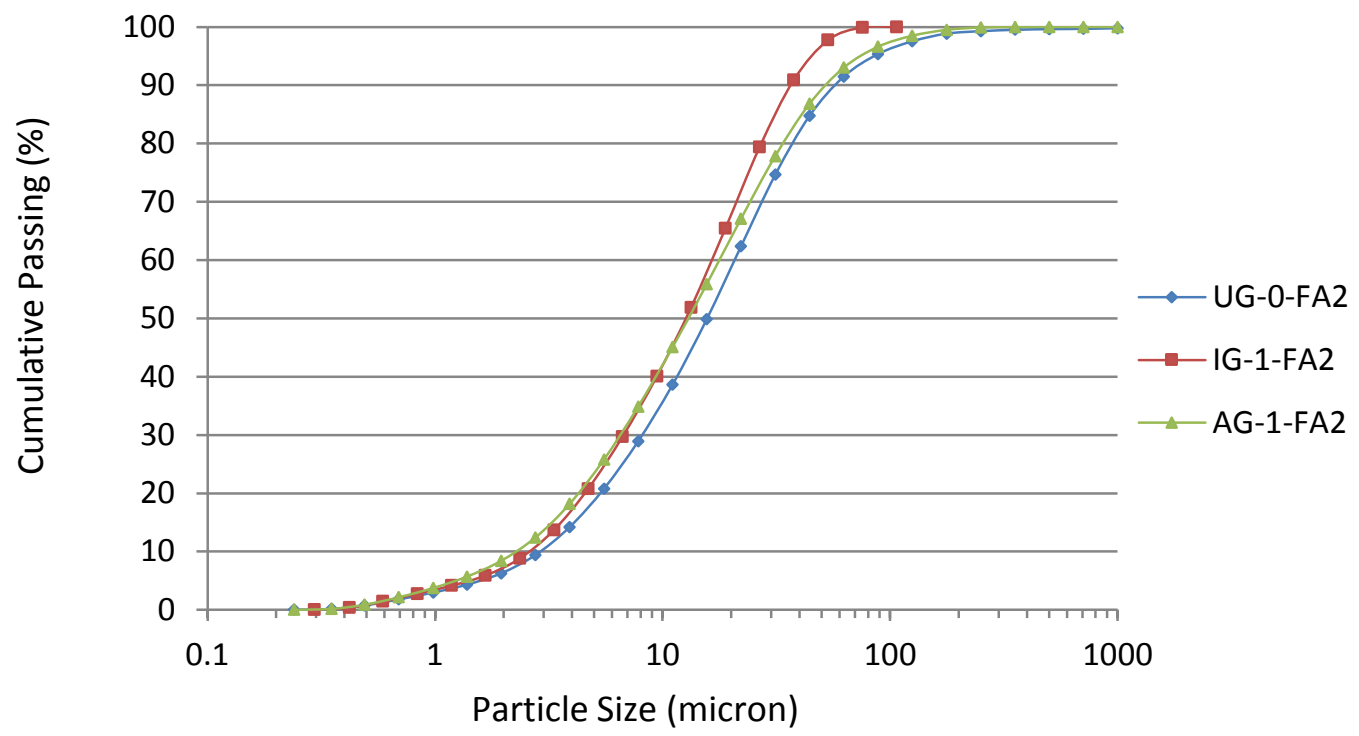

(b)

$514 \quad$ Figure 5: Particle size distribution plots comparing unground blends with one hour interground blends and 515 activator ground blends (after unground fly ash has been added) made with (a) fly ash 1 and (b) fly ash 2 516 


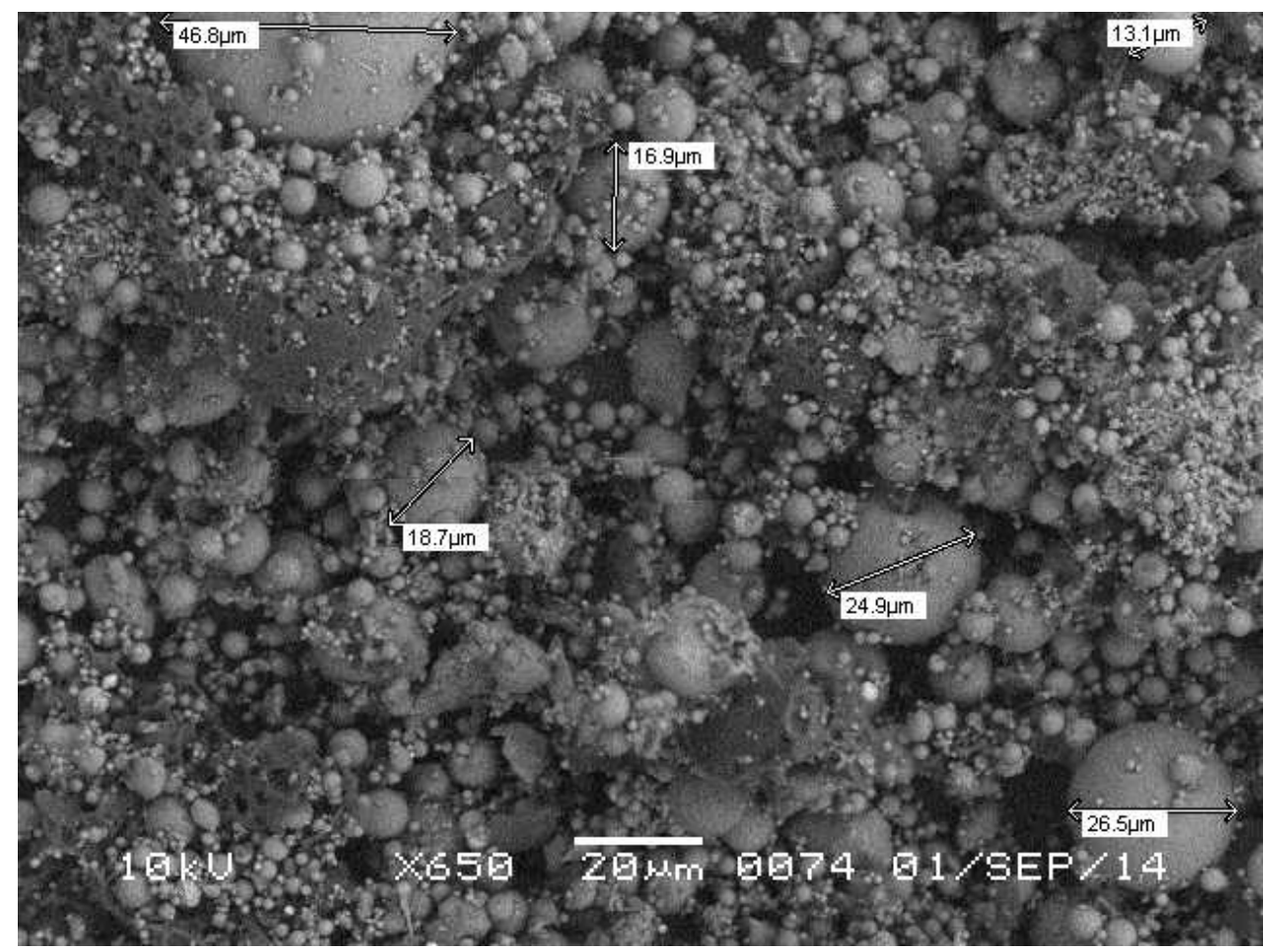

(a) FA1

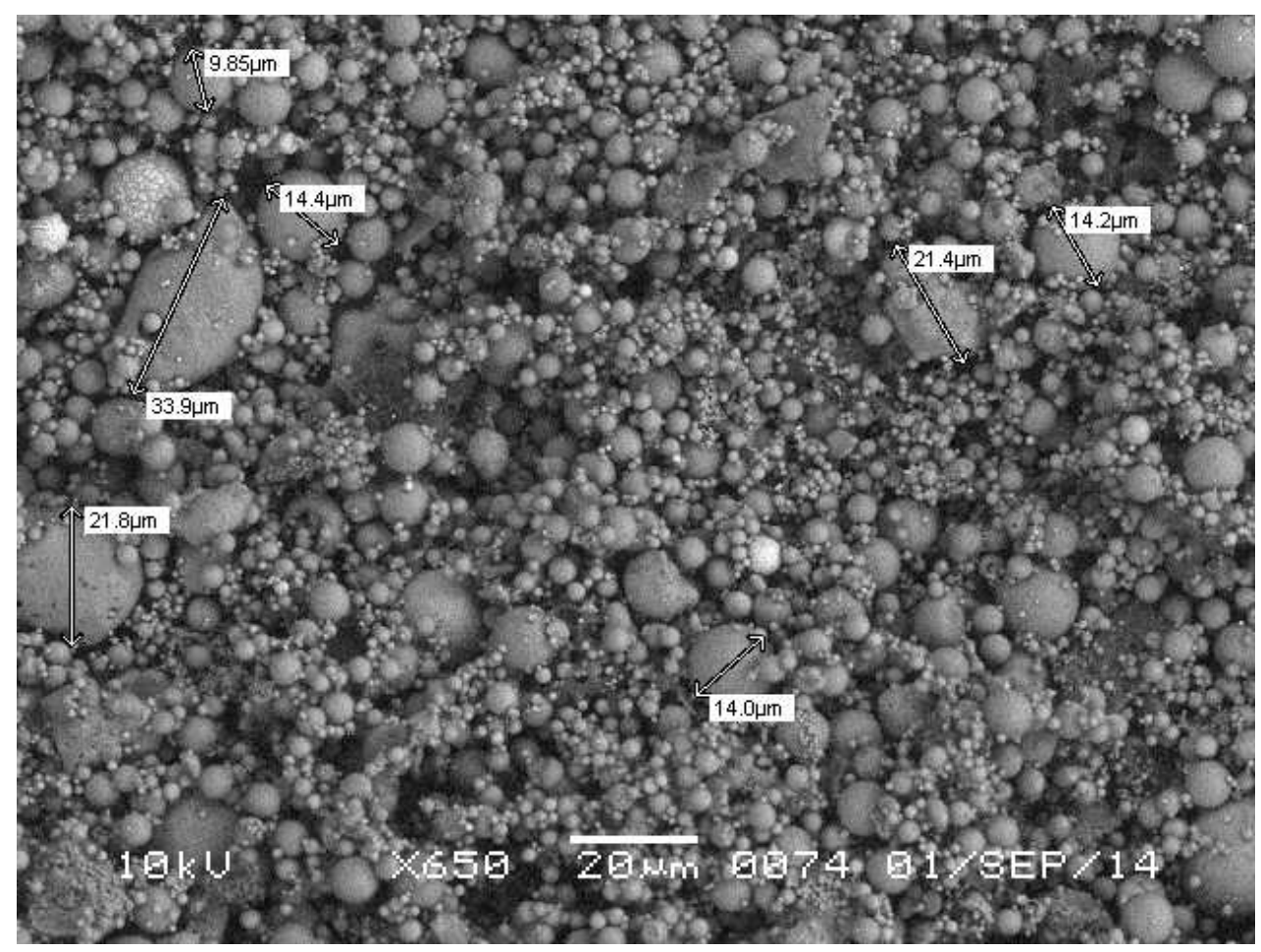

(b) FA2 


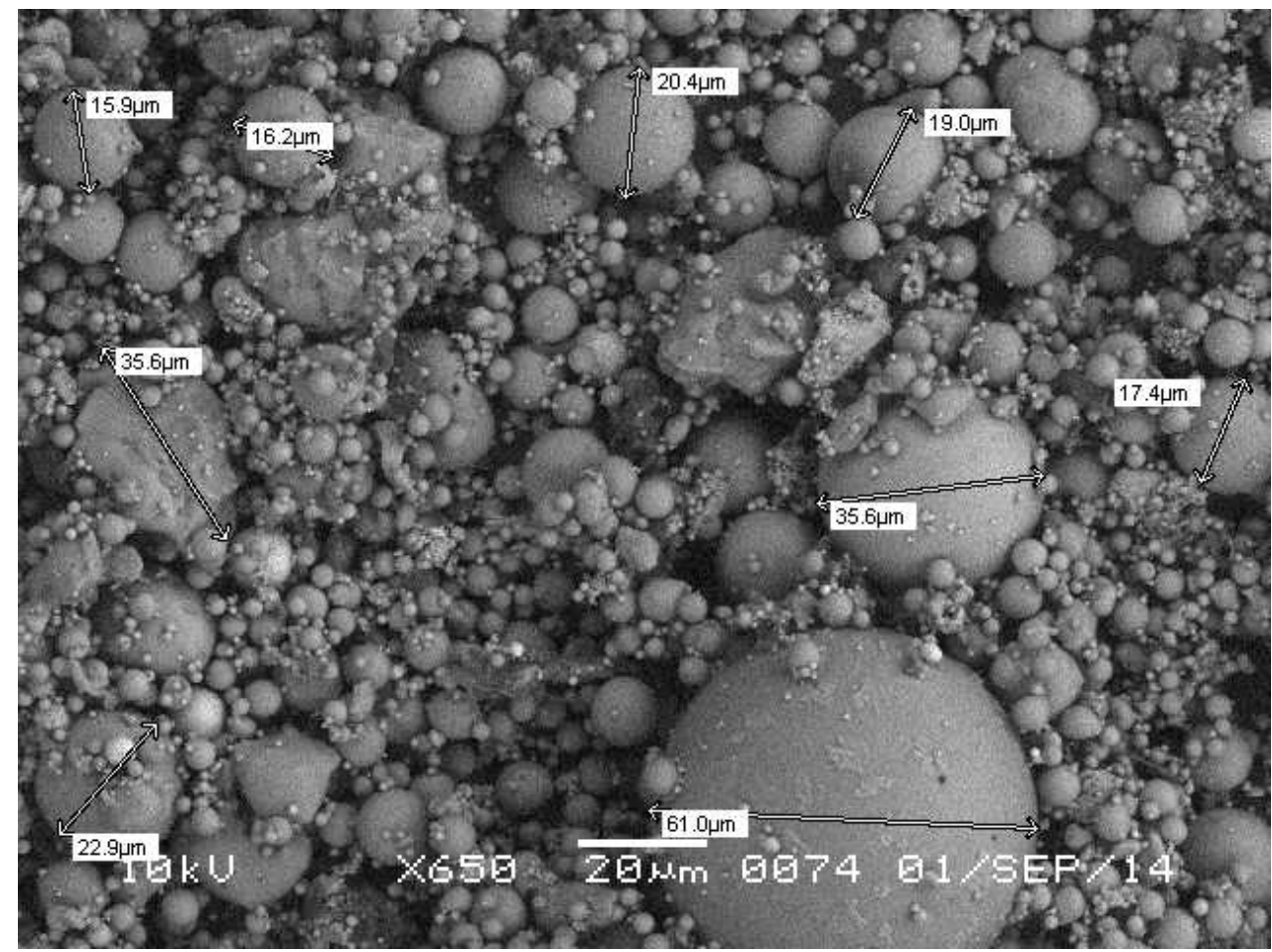

\section{(c) $\mathrm{FA3}$}

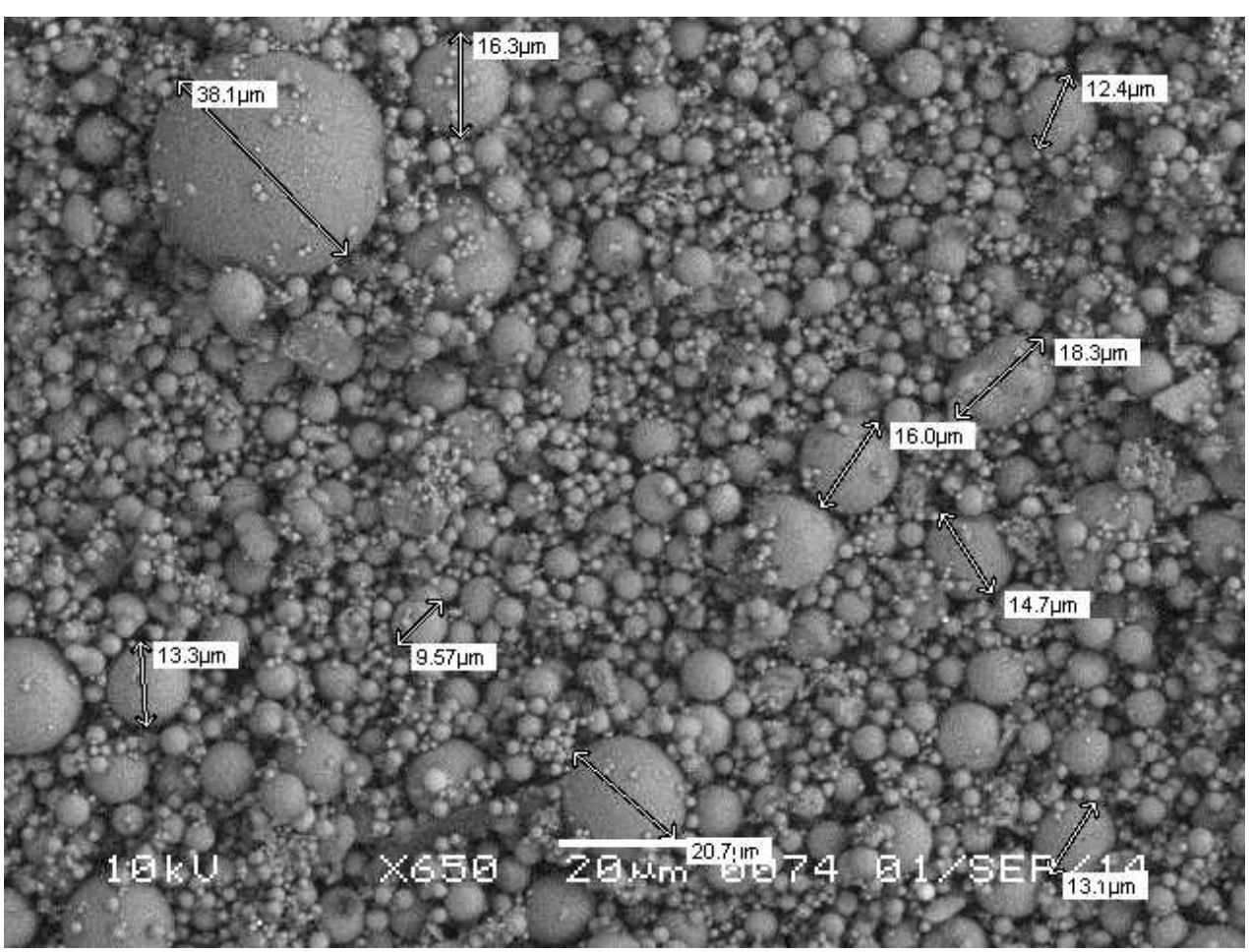

(d) FA4 

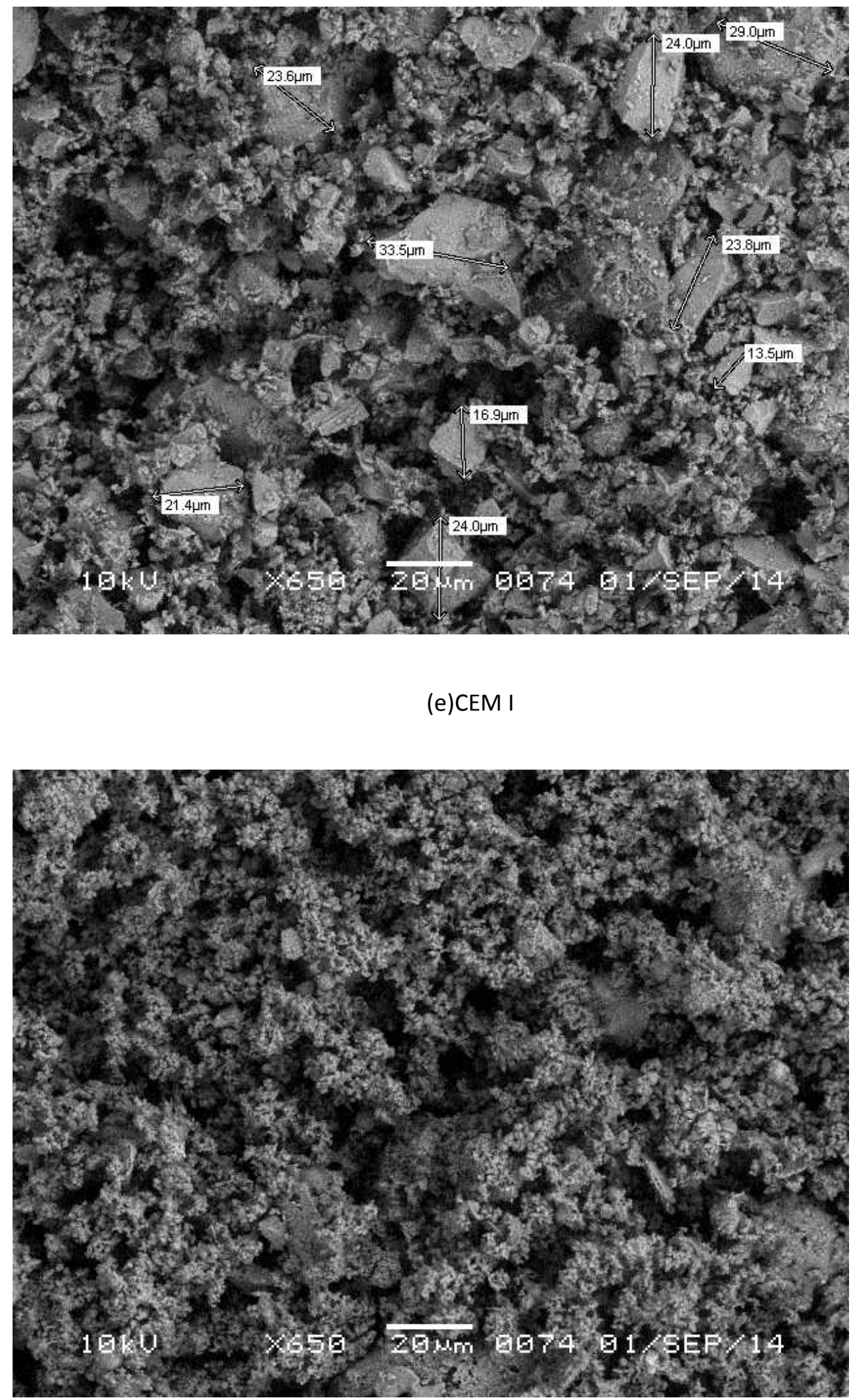


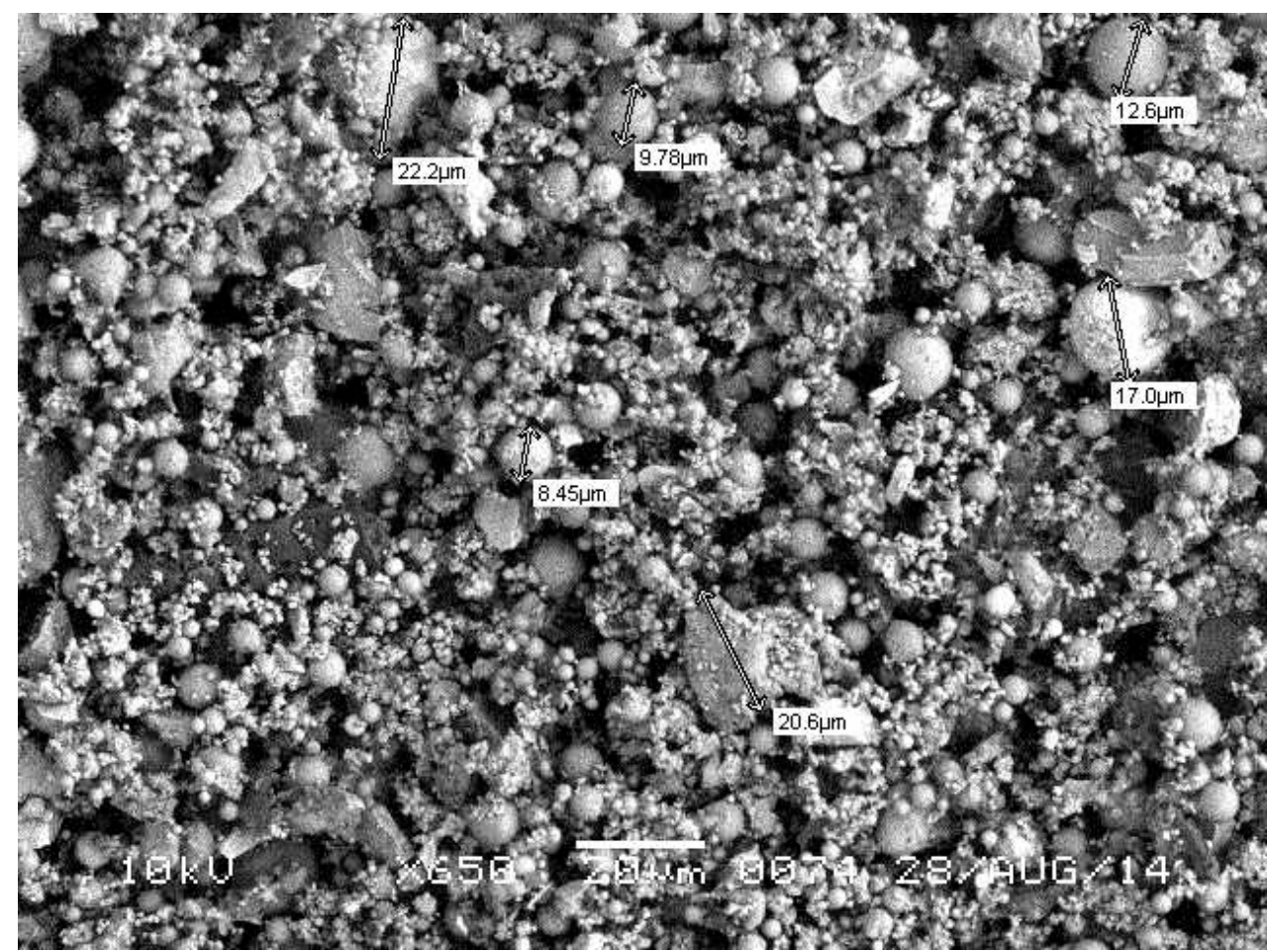

(a) IG-1-FA1

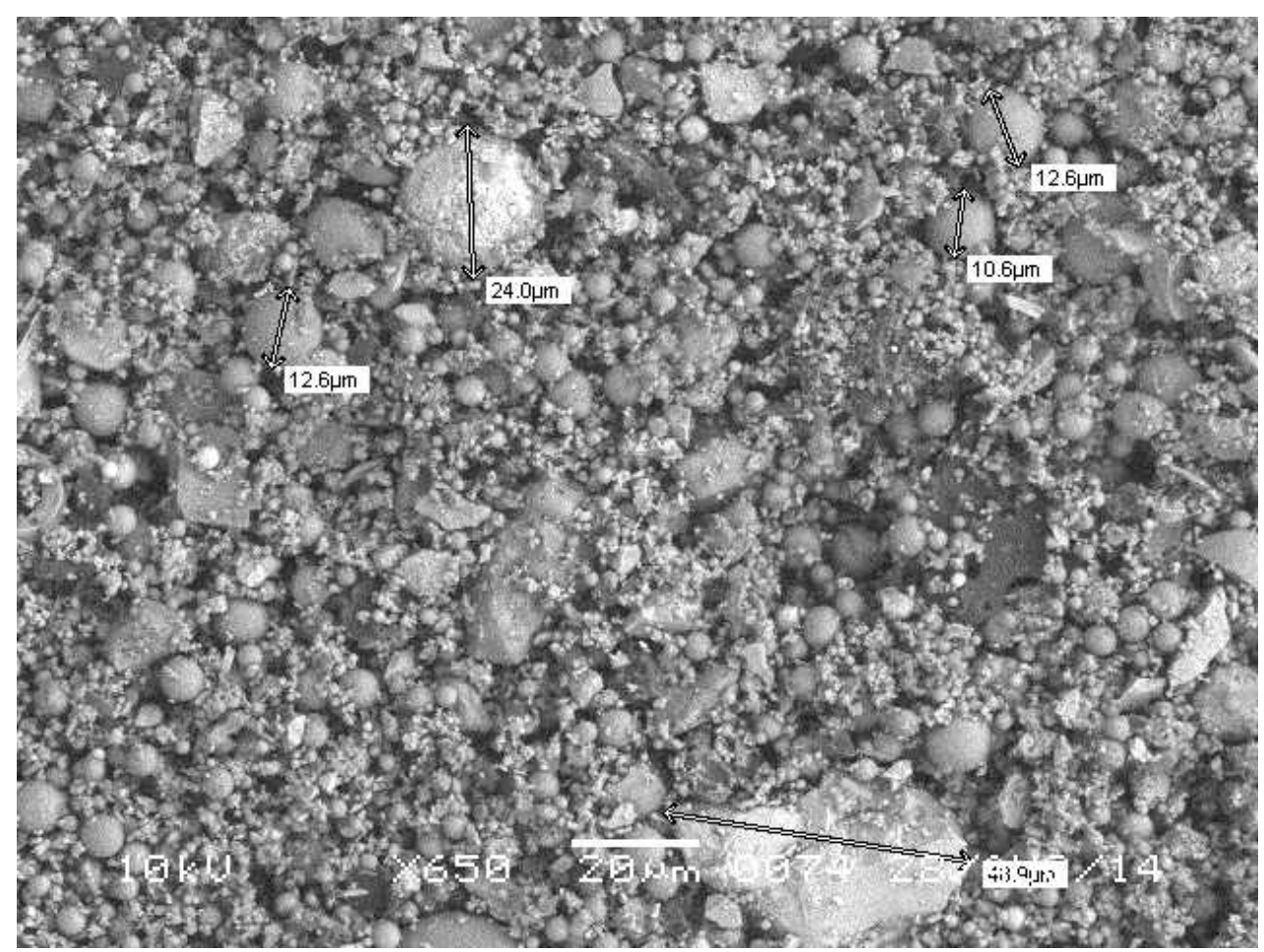

(b) IG-2-FA1 


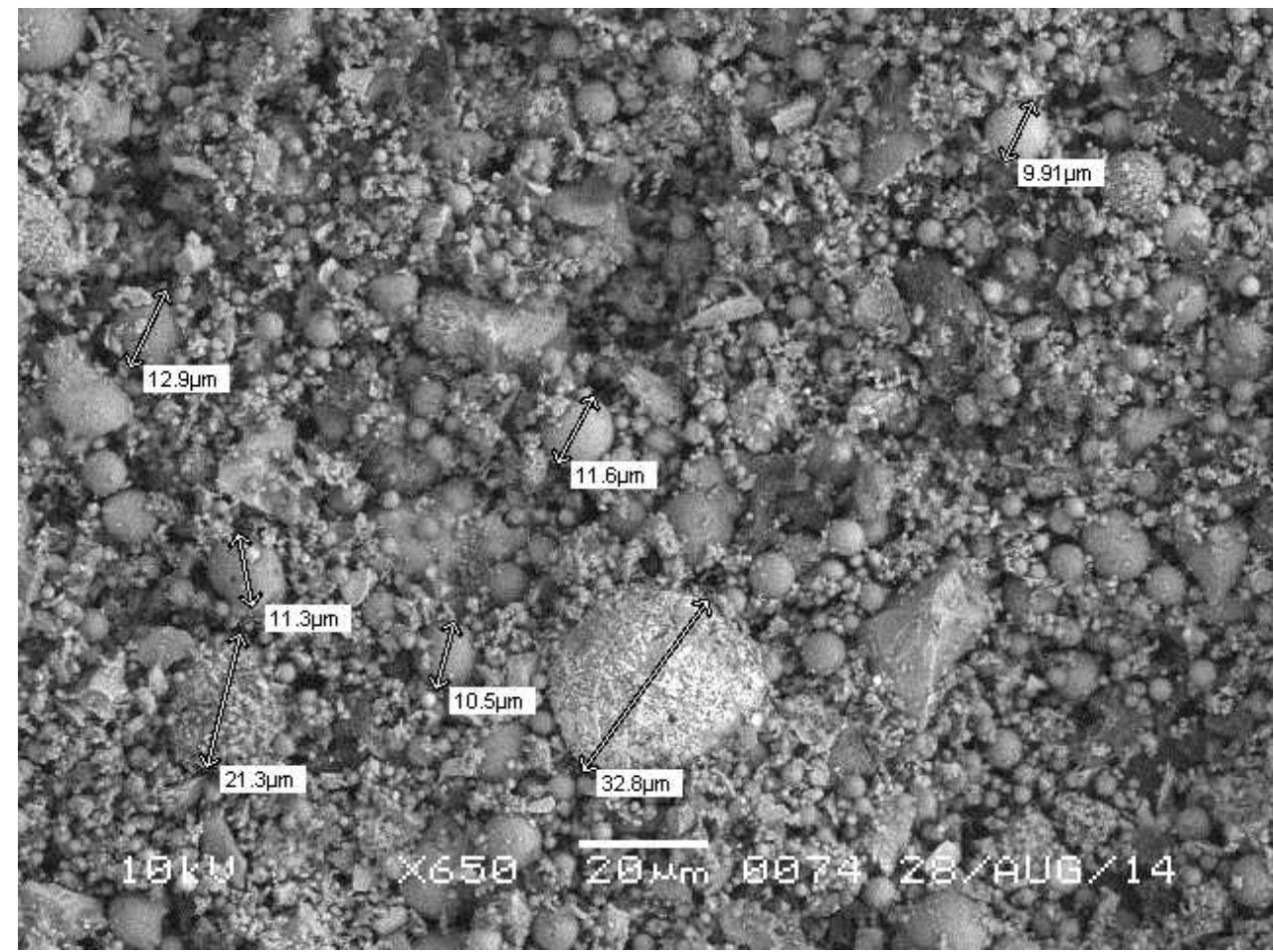

(c) IG-4-FA1

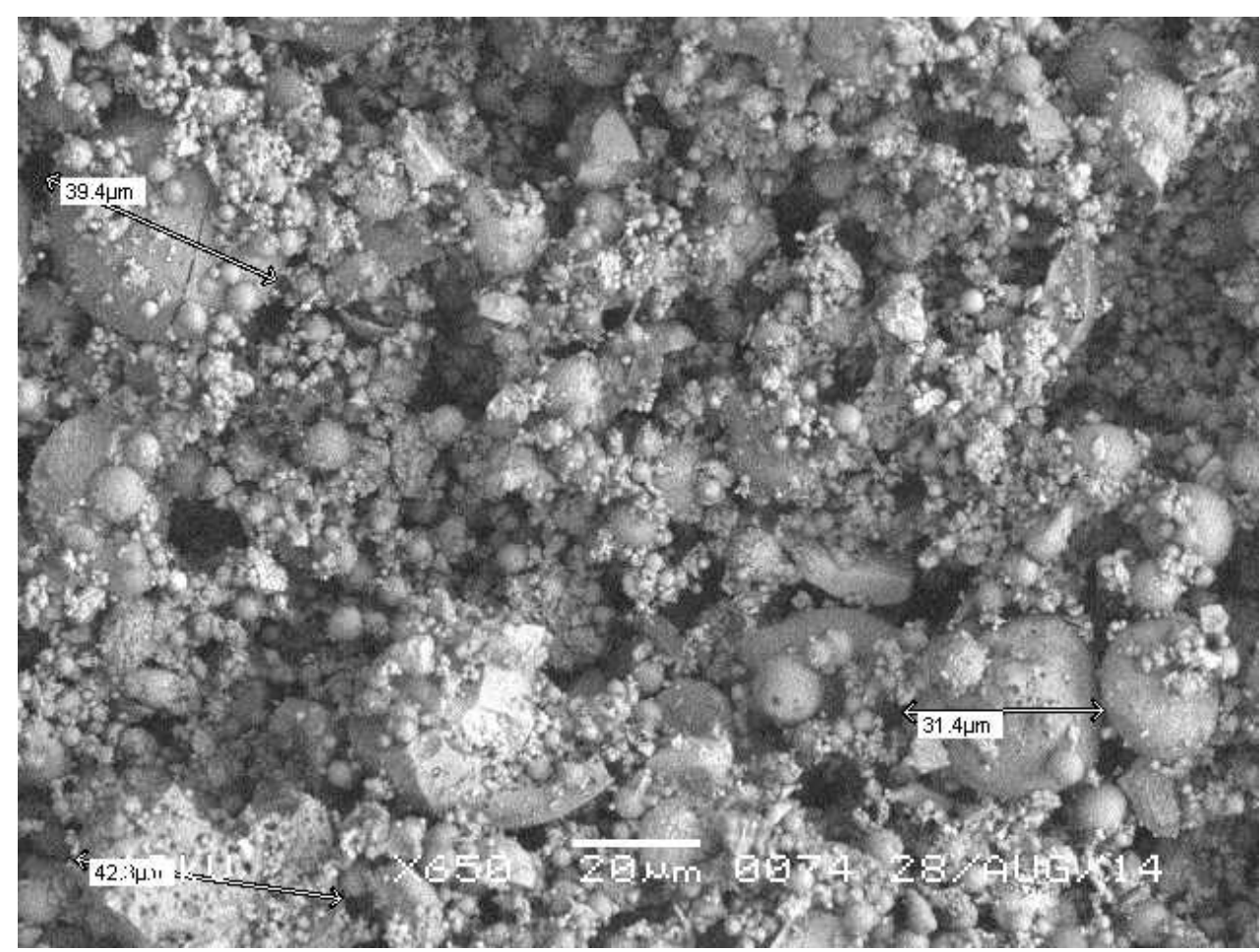

(d) IG-1-FA2 

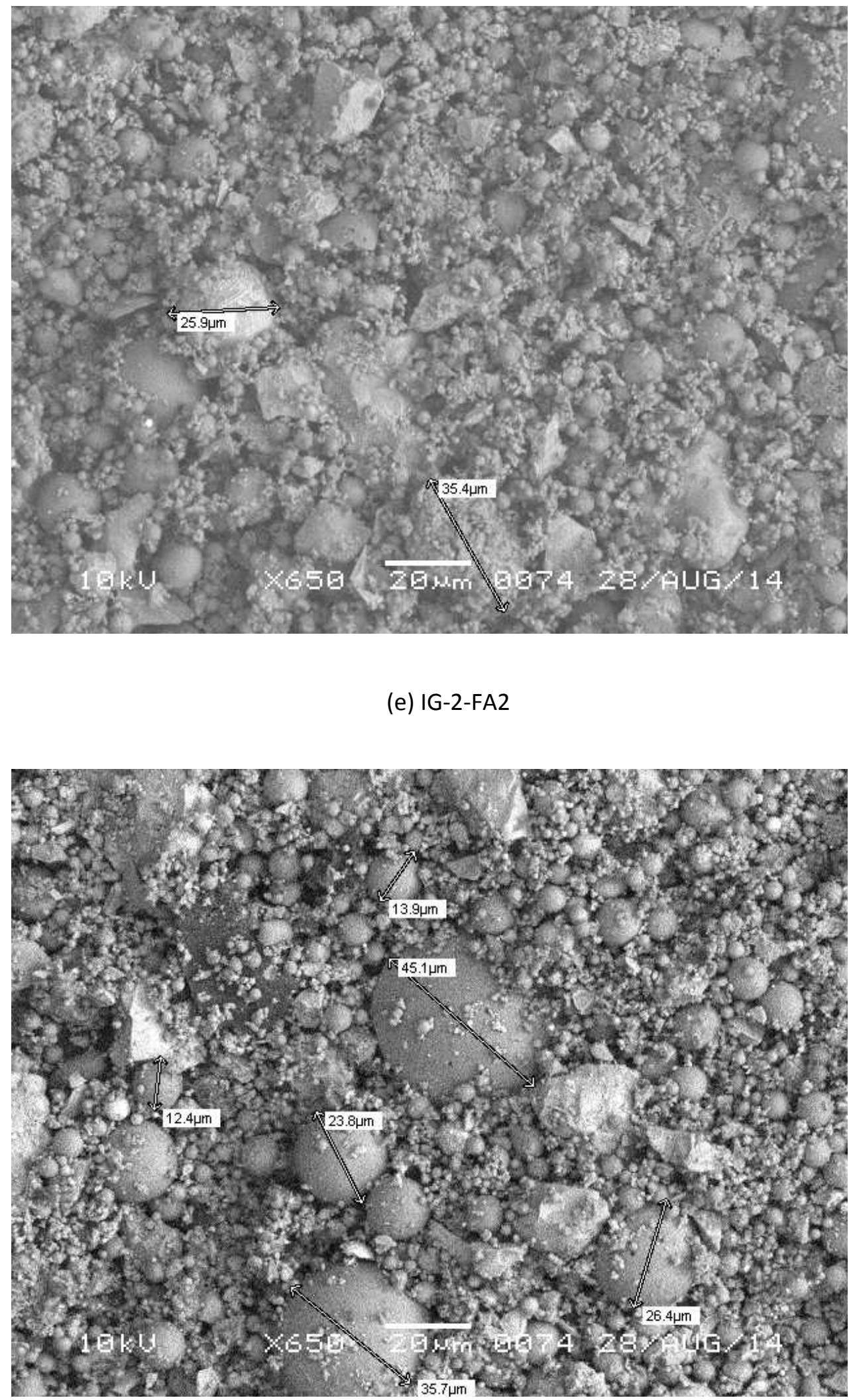


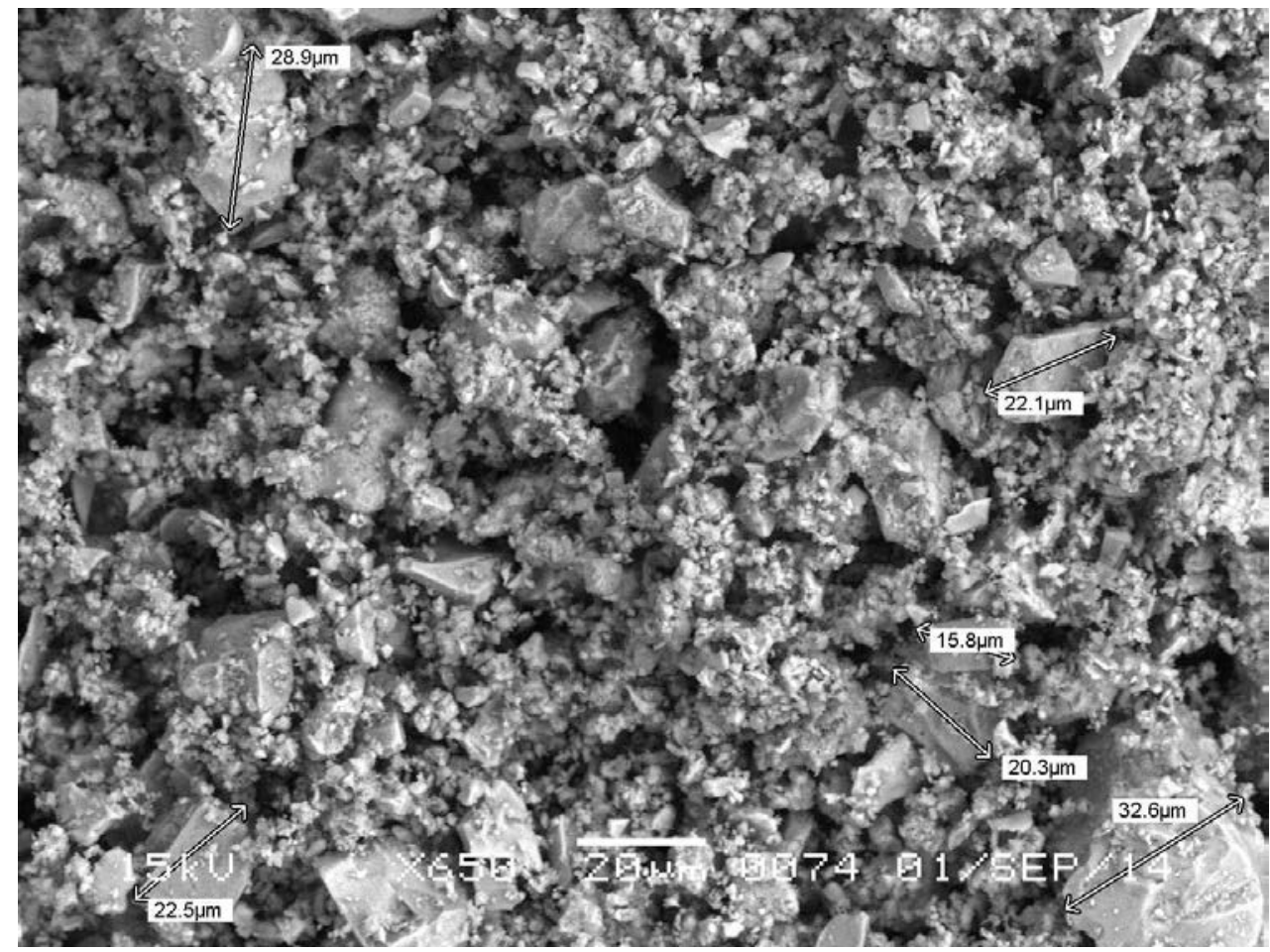

(a) AG-1

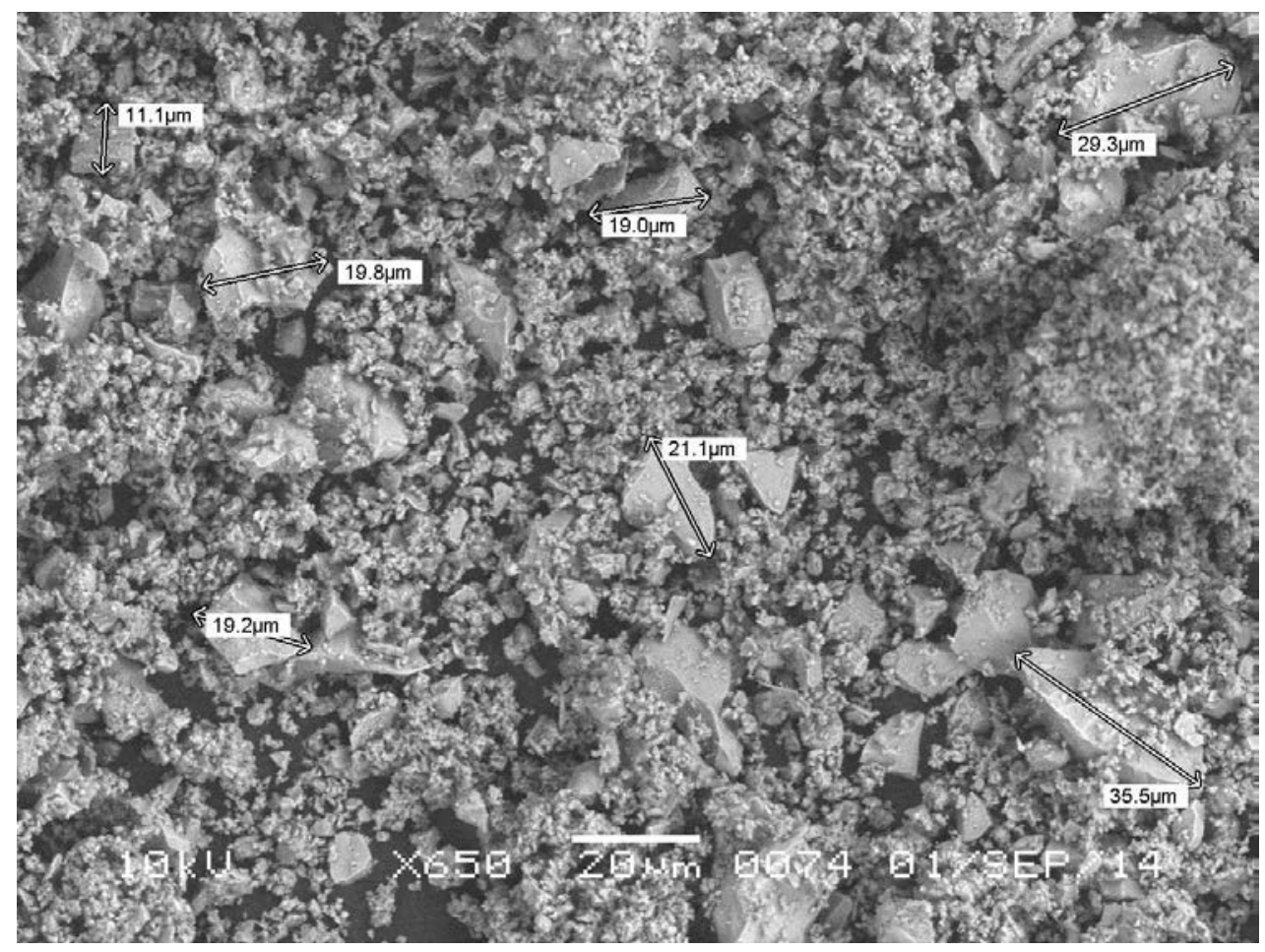

(b) AG-2 
564

565

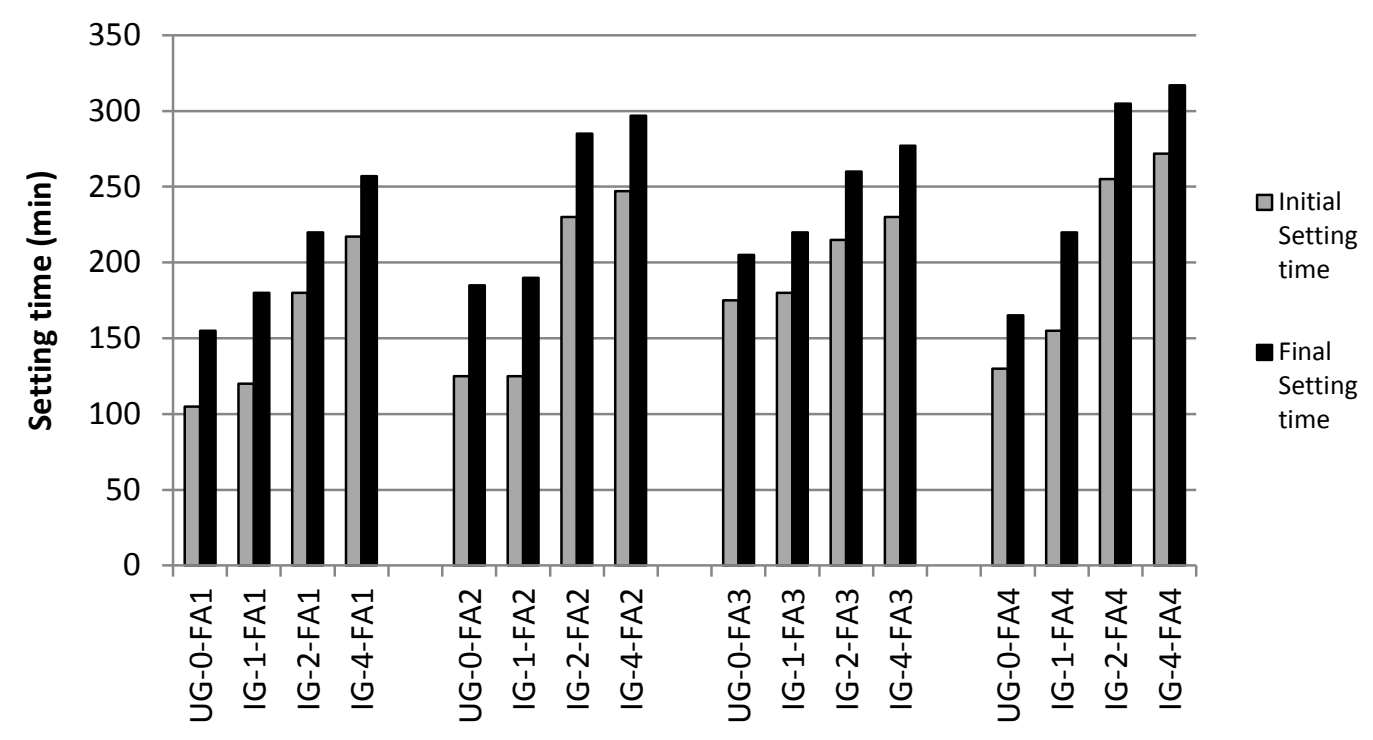

(a)

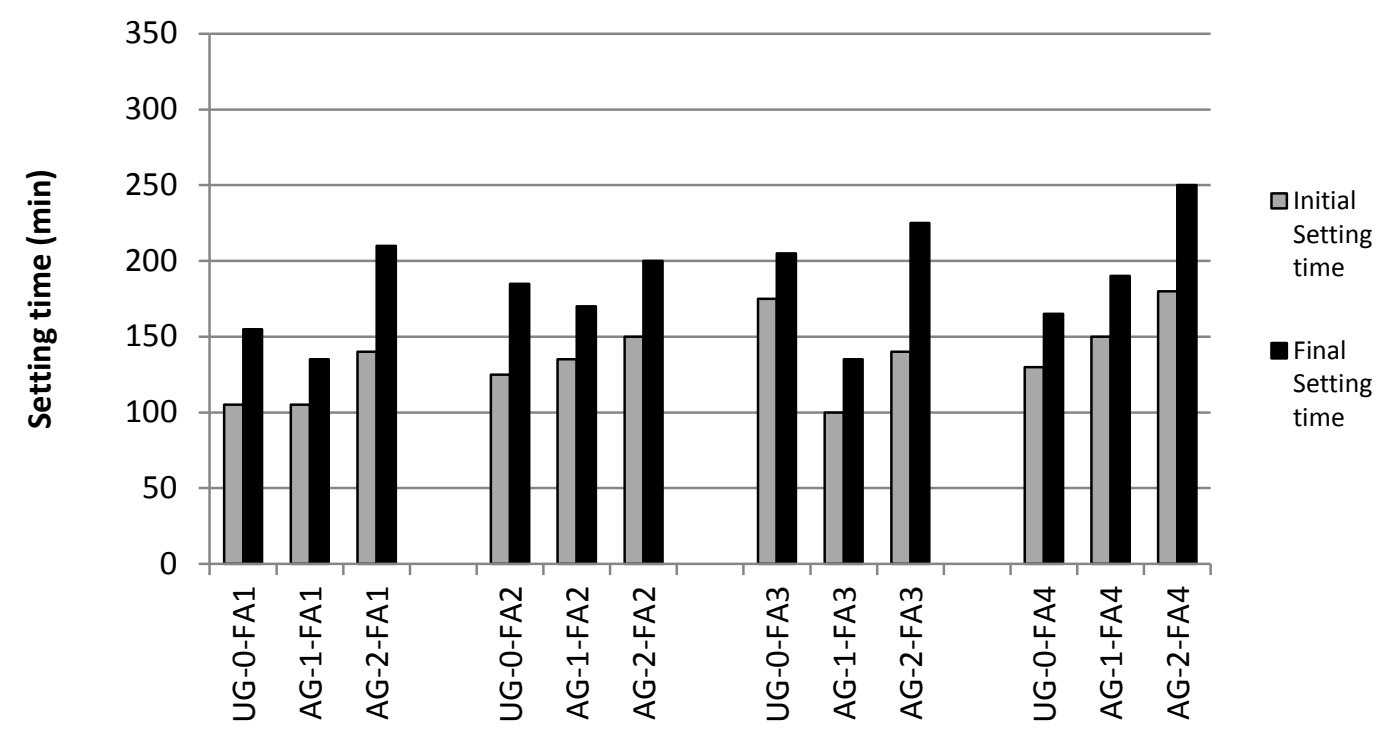

(b)

Figure 9: Initial and final setting times for control pastes and (a) pastes made with interground constituents and (b) pastes made with unground ash and ground activators 


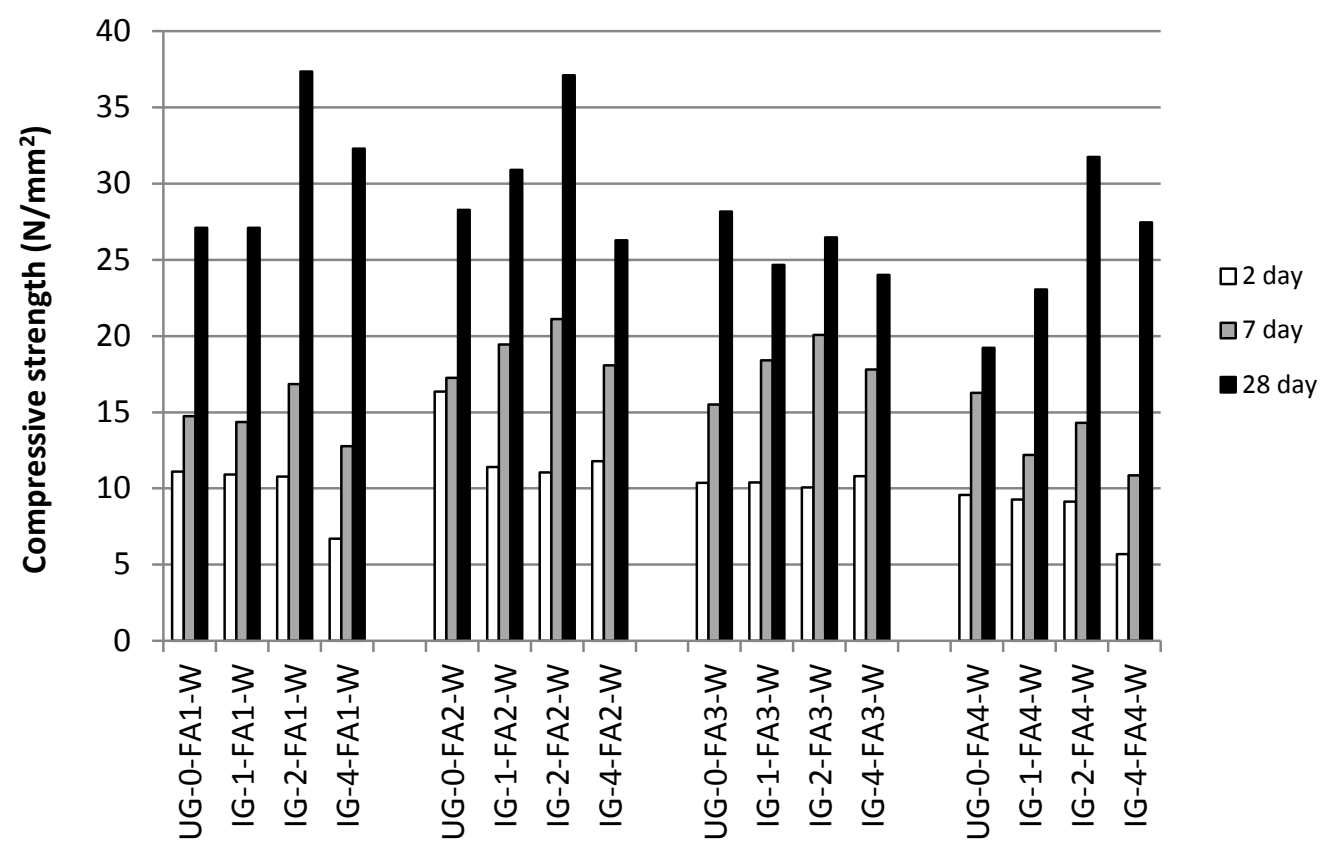

(a)

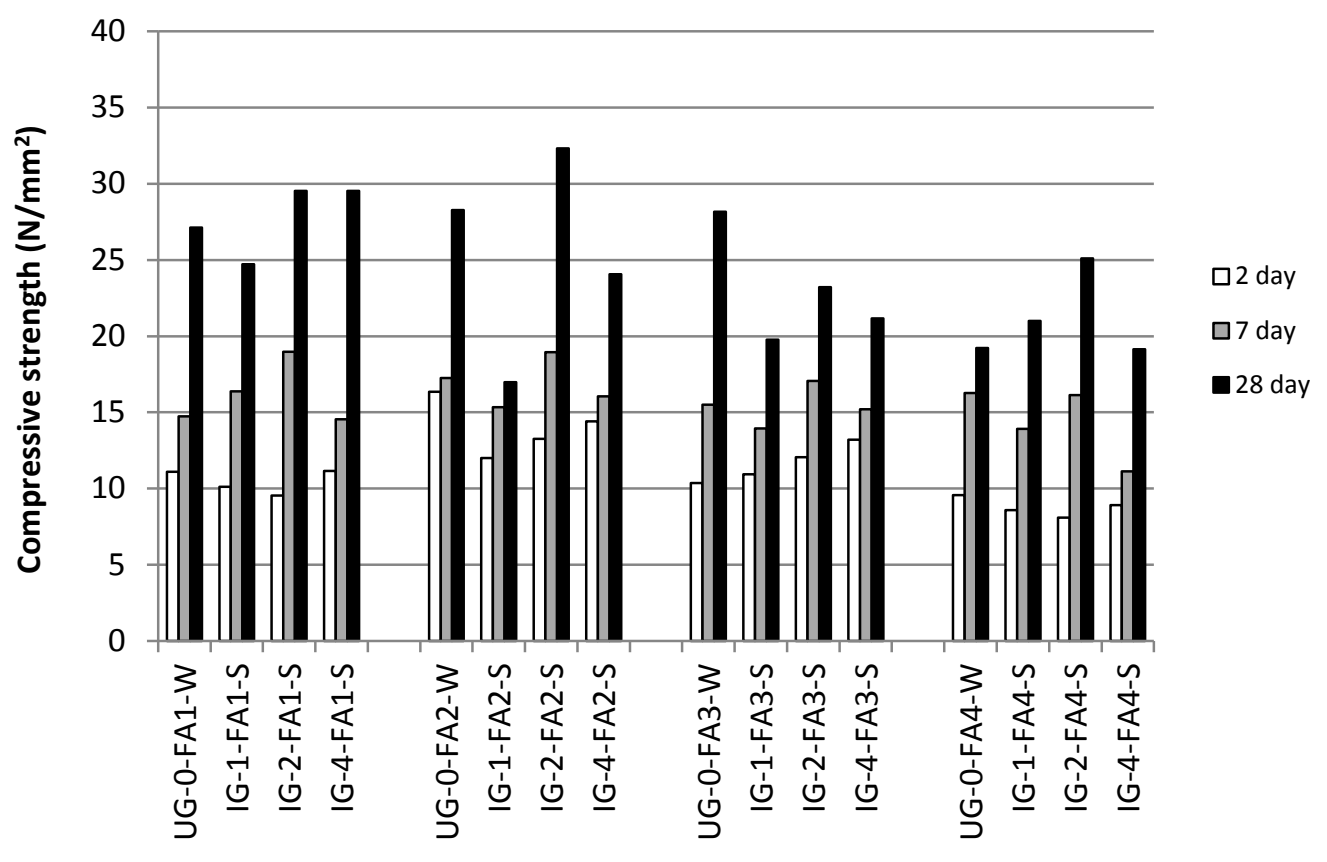

(b)

582 Figure 10: Compressive strength of paste samples interground for varying time periods for (a) wrapped curing and 583

(b) submerged curing 


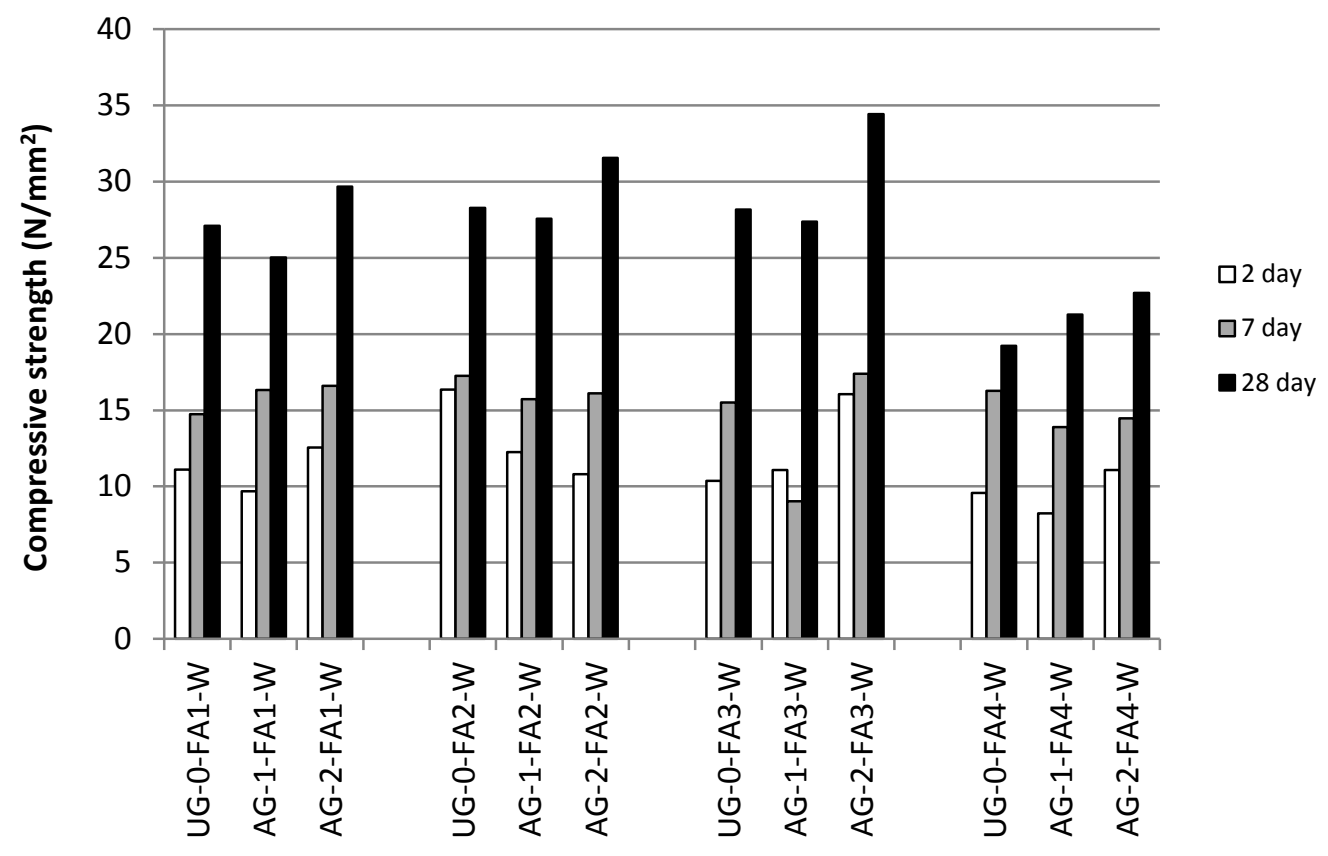

(a)

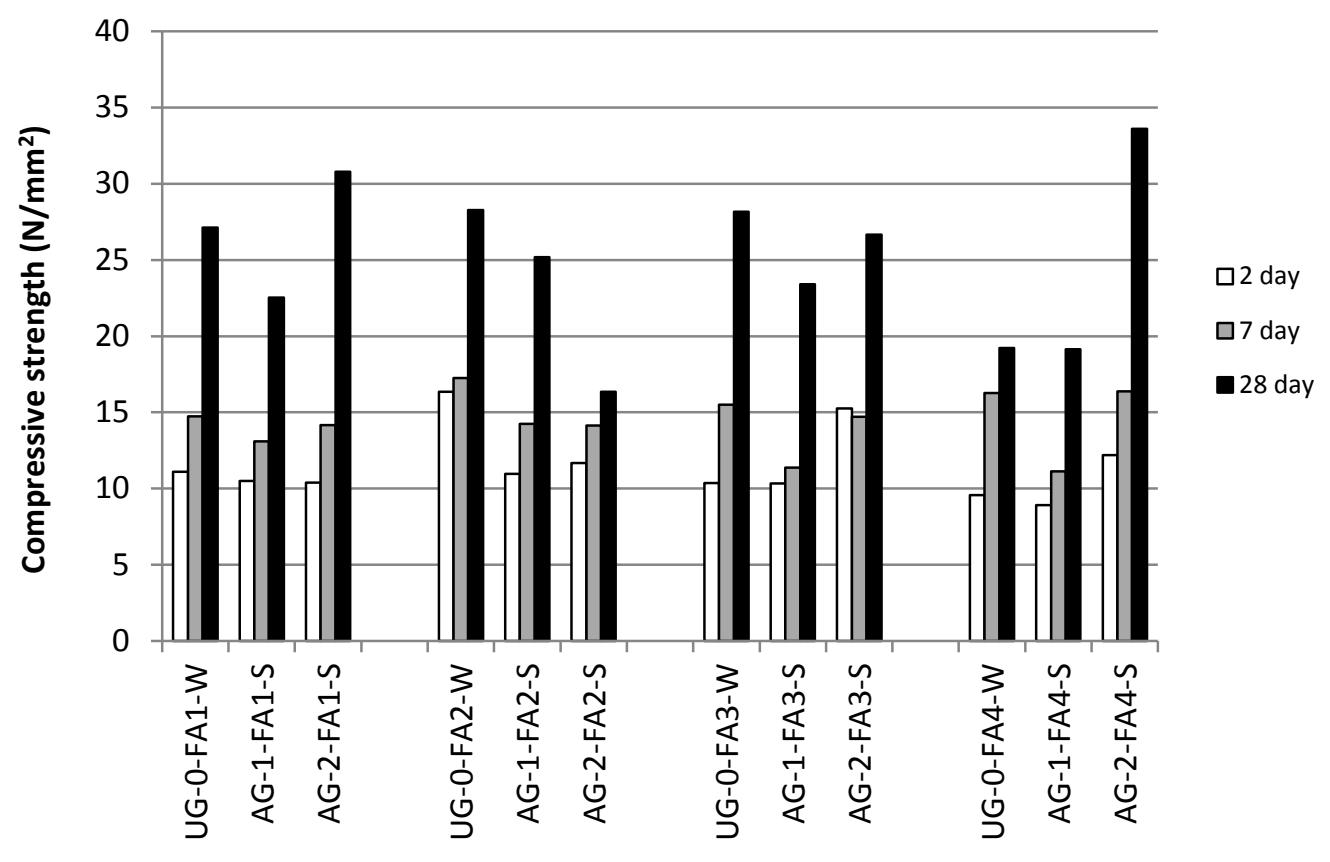

(b)

Figure 11: Compressive strength of paste samples with activators only ground for varying time periods for (a) 


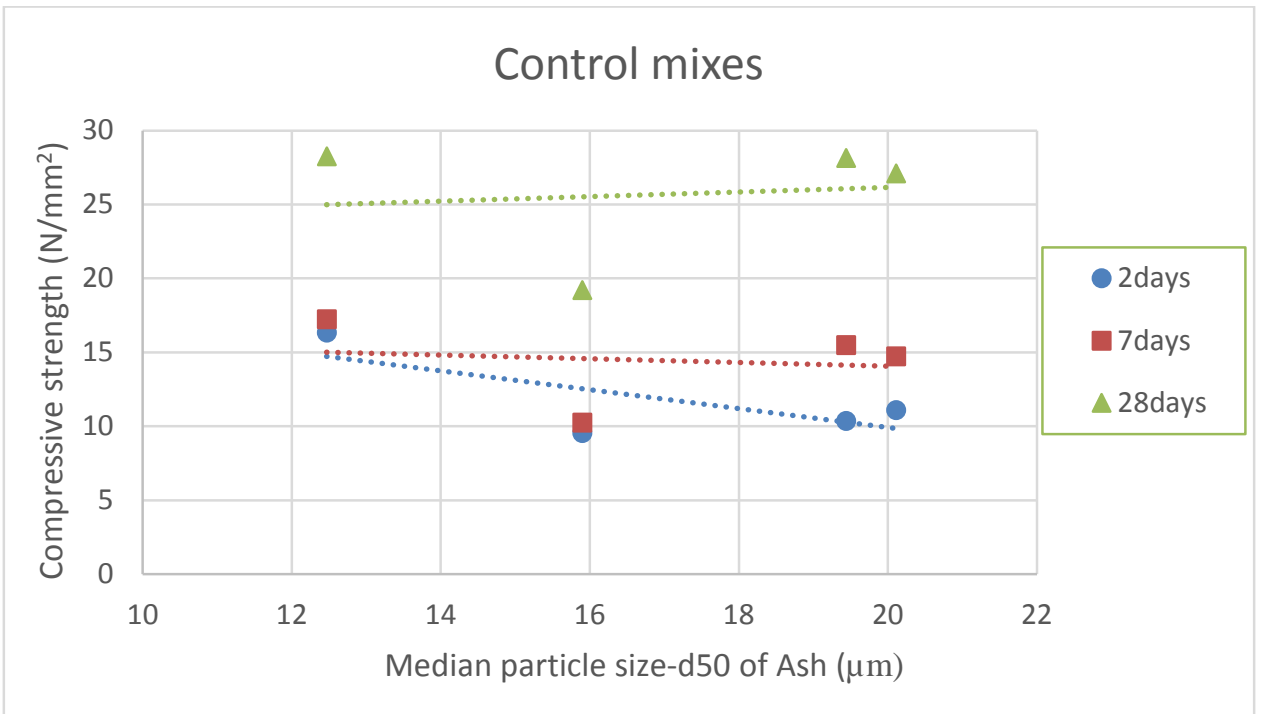

Figure 12: Compressive strength of control paste samples for varying median particle size of different ashes

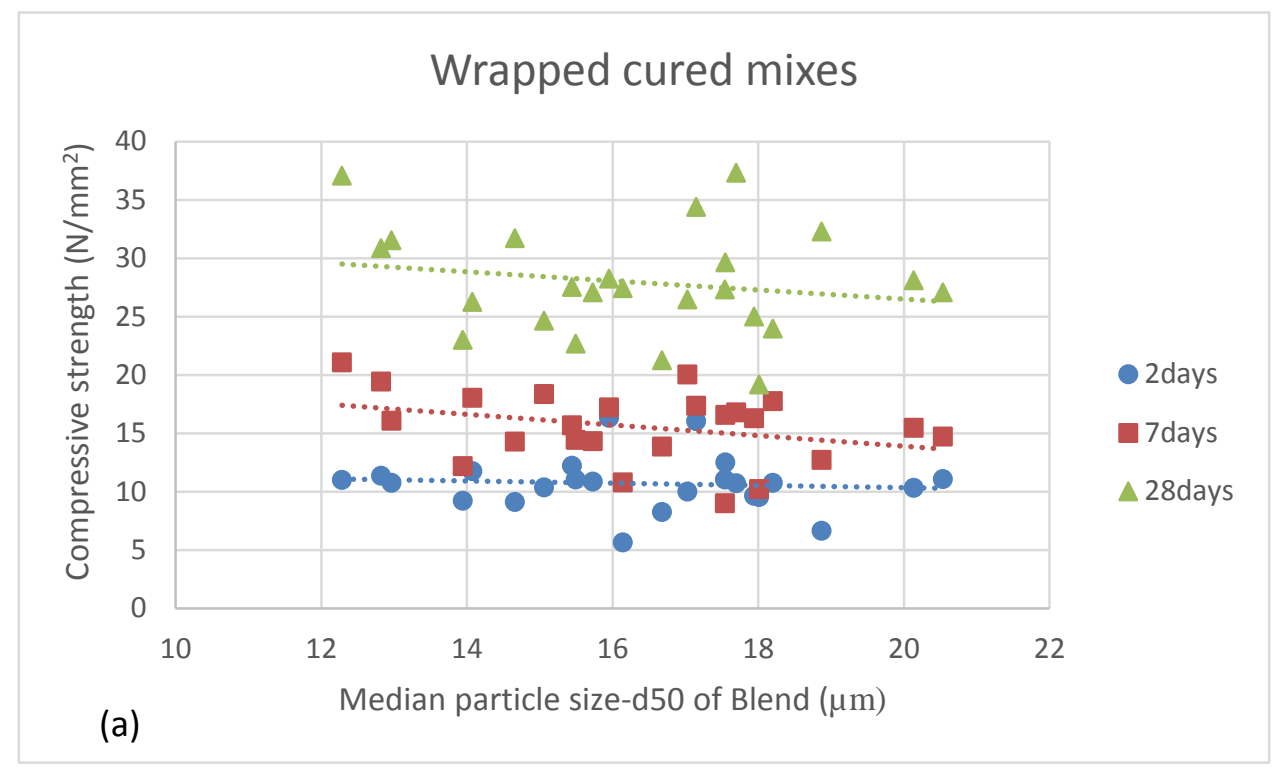

\section{Submerged cured mixes}

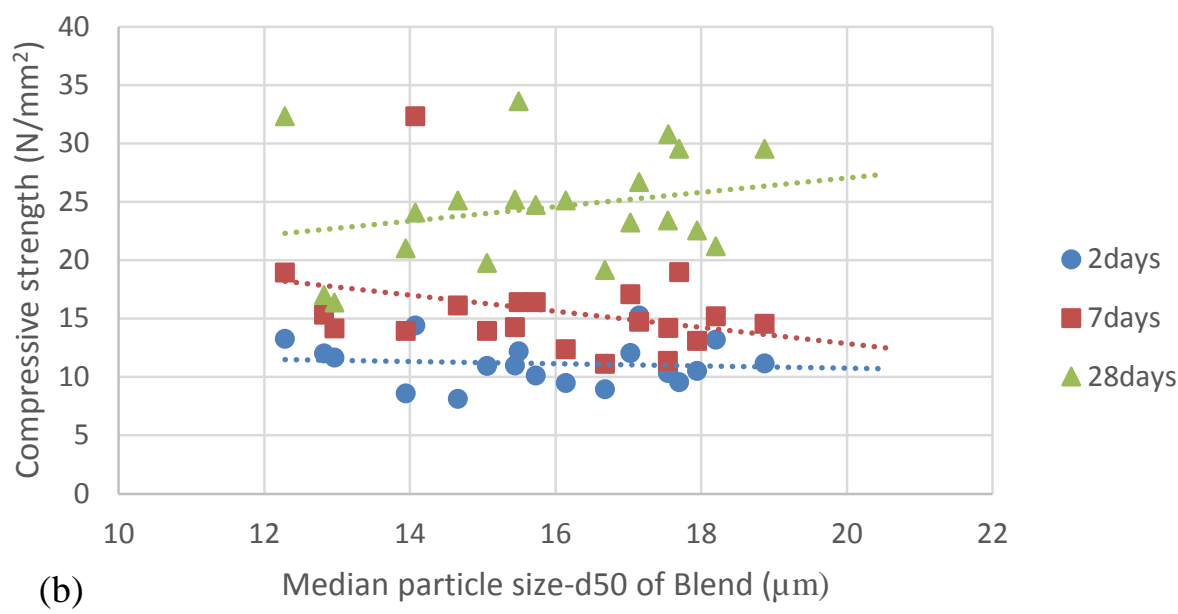

601 Figure 13: Compressive strength of paste samples for varying median particle size of blend for (a) wrapped curing 


\section{Acknowledgement}

605 This work was supported by the Engineering and Physical Sciences Research Council (EPSRC) under Grant 606 [EP/J016055/1]. The authors gratefully acknowledge the Engineering and Physical Sciences Research Council for 607 funding.

608

609 References

610 [1] Bondar D. and Coakley E. (2014) 'Use of Gypsum and CKD to enhance early age strength of High Volume Fly Ash 611 (HVFA) pastes'. Construction and Building Materials, 71, 93-108.

612

613 [2] Erdogdu K. and Turker P. (1998) 'Effects of fly ash particle size on strength of Portland cement fly ash mortars'.

614 Cement and Concrete Research, 28(9), 1217-1222.

615

616 [3] Chindaprasirt P., Homwuttiwong S. and Sirivivatnanon V. (2004) 'Influence of fly ash fineness on strength, drying 617 shrinkage and sulfate resistance of blended cement mortar'. Cement and Concrete Research, 34, 1087-1092. 618

619 [4] Chindaprasirt P., Jaturapitakkul C. and Sinsiri T. (2005) 'Effect of fly ash fineness on compressive strength and 620 pore size of blended cement paste'. Cement and Concrete Composites, 27, 425-428.

622 [5] Kiattikomol K., Jaturapitakkul C., Songpiriyakij S. and Chutubtim S. (2001) 'A study of ground coarse fly ashes 623 with different finenesses from various sources as pozzolanic materials'. Cement and Concrete Composites, 23, 335624343.

626 [6] Aydin S., Karatay C. and Baradan B. (2010) 'The effect of grinding process on mechanical properties and alkali627 silica reaction resistance of fly ash incorporated cement mortars'. Powder Technology, 197, 68-72.

629 [7] Paya J., Monzo J., Borrachero M.V. and Peris-Mora E. (1995) 'Mechanical treatment of fly ashes Part I: Physico630 chemical characterization of ground fly ashes'. Cement and Concrete Research, 25(7), 1469-1479.

632 [8] Felekoglo B., Turkel S. and Kalyoncu H. (2009) 'Optimization of fineness to maximize the strength activity of high633 calcium ground fly ash-Portland cement composites'. Construction and Building Materials, 23, 2053-2061.

635 [9] Paya J., Monzo J., Borrachero M.V., Peris-Mora E. and Amahjour F. (2000) 'Mechanical treatment of fly ashes 636 Part IV: Strength development of ground fly ash-cement mortars cured at different temperatures'. Cement and 637 Concrete Research, 30, 543-551. 
639 [10] Bouzoubaa N., Zhang M.H., Bilodeau A. and Malhotra V.M. (1997) 'The effect of grinding on the physical 640 properties of fly ashes and a Portland cement clinker'. Cement and Concrete Research, 27(12), 1861-1874. 641

642 [11] Wang K., Mishulovich A. and Shah S.P. (2007) 'Activations and properties of cementitious materials made with 643 cement-kiln dust and class-F fly ash'. Journal of Materials in Civil Engineering (ASCE), 19, 112-119. 644

645 [12] Bouzoubaa N., Zhang M.H., Bilodeau A. and Malhotra V.M. (1998) 'Laboratory-produced high-volume fly ash 646 blended cements: Physical properties and compressive strength of mortars'. Cement and Concrete Research, 647 28(11), 1555-1569.

648

649 [13] Ghiasvand E., Ramezanianpour A.A. and Ramezanianpour A.M. (2014) 'Effect of grinding method and particle 650 size distribution on the properties of Portland-pozzolan cement'. Construction and Building Materials, 53, 547-554. 651

652 [14] Erdogdu K., Tokyoy M. and Turker P. (1999) 'Comparison of intergrinding and separate grinding for the 653 production of natural pozzolan and GBFS-incorporated blended cements'. Cement and Concrete Research, 29, $654743-746$.

655

656 [15] Ryou J. (2004) 'Improvement on reactivity of cementitious waste materials by mechanochemical activation'. 657 Materials Letters, 58, 903-906.

658

659 [16] Bentz D.P., Hansen A.S. and Guynn J.M. (2011) 'Optimization of cement and fly ash particle sizes to produce 660 sustainable concretes'. Cement and Concrete Composites, 33, 824-831.

661

662 [17] Kunal, Siddique R. and Rajor A. (2012) 'Use of cement kiln dust in cement concrete and its leachate 663 characteristics'. Resources, Conservation and Recycling, 61, 59-68. 